\title{
Sources and accumulation of organic carbon in the Pearl River Estuary surface sediment as indicated by elemental, stable carbon isotopic, and carbohydrate compositions
}

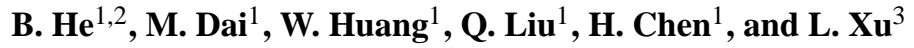 \\ ${ }^{1}$ State Key Laboratory of Marine Environmental Science, Xiamen University, Xiamen 361005, China \\ ${ }^{2}$ School of Bioengineering, Jimei University, Xiamen 361021, China \\ ${ }^{3}$ Woods Hole Oceanographic Institution, Woods Hole, Ma 02543, USA
}

Received: 1 March 2010 - Published in Biogeosciences Discuss.: 22 April 2010

Revised: 1 October 2010 - Accepted: 6 October 2010 - Published: 28 October 2010

\begin{abstract}
Organic matter in surface sediments from the upper reach of the Pearl River Estuary and Lingdingyang Bay, as well as the adjacent northern South China Sea shelf was characterized using a variety of techniques, including elemental $(\mathrm{C}$ and $\mathrm{N})$ ratio, bulk stable organic carbon isotopic composition $\left(\delta^{13} \mathrm{C}\right)$, and carbohydrate composition analyses. Total organic carbon (TOC) content was $1.21 \pm 0.45 \%$ in the upper reach, down to $1.00 \pm 0.22 \%$ in Lingdingyang Bay and to $0.80 \pm 0.10 \%$ on the inner shelf and $0.58 \pm 0.06 \%$ on the outer shelf. $\delta^{13} \mathrm{C}$ values ranged from $-25.1 \%$ o to $-21.3 \%$ o in Lingdingyang Bay and the South China Sea shelf, with a trend of enrichment seawards. The spatial trend in $\mathrm{C} / \mathrm{N}$ ratios mirrored that of $\delta^{13} \mathrm{C}$, with a substantial decrease in $\mathrm{C} / \mathrm{N}$ ratio offshore. Total carbohydrate yields ranged from 22.1 to $26.7 \mathrm{mg}(100 \mathrm{mg} \mathrm{OC})^{-1}$, and typically followed TOC concentrations in the estuarine and shelf sediments. Total neutral sugars, as detected by the nine major monosaccharides (lyxose, rhamnose, ribose, arabinose, fucose, xylose, galactose, mannose, and glucose), were between 4.0 and $18.6 \mathrm{mg}$ $(100 \mathrm{mg} \mathrm{OC})^{-1}$ in the same sediments, suggesting that significant amounts of carbohydrates were not neutral aldoses. Using a two end-member mixing model based on $\delta^{13} \mathrm{C}$ values and $\mathrm{C} / \mathrm{N}$ ratios, we estimated that the terrestrial organic carbon contribution to the surface sediment TOC was ca. $78 \pm 11 \%$ for Lingdingyang Bay, $34 \pm 4 \%$ for the inner shelf, and $5.5 \pm 1 \%$ for the outer shelf. The molecular composition of the carbohydrate in the surface sediments also suggested that the inner estuary was rich in terrestrially derived carbohydrates but that their contribution decreased offshore. A relatively high abundance of deoxyhexoses in the estuary and
\end{abstract}

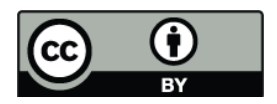

Correspondence to: M. Dai (mdai@xmu.edu.cn) shelf indicated a considerable bacterial source of these carbohydrates, implying that sediment organic matter had undergone extensive degradation and/or transformation during transport. Sediment budget based on calculated regional accumulation rates showed that only $\sim 50 \%$ of the influxes of terrestrial organic carbon were accumulated in the estuary. This relatively low accumulation efficiency of terrestrial organic matter as compared to the total suspended solids (accumulation efficiency $\sim 73 \%$ ) suggested significant degradation of the terrestrial organic carbon within the estuarine system after its discharge from the river. This study demonstrated that the combination of the bulk organic matter properties together with the isotopic composition and molecular-level carbohydrate compositions can be an efficient way to track down the source and fate of organic matter in highly dynamic estuarine and coastal systems. The predominance of terrestrially originated organic matter in the sediment and its generally low accumulation efficiency within the estuary is not surprising, and yet it may have important implications in light of the heavy anthropogenic discharges into the Pearl River Estuary during the past thirty years.

\section{Introduction}

Understanding the fate of terrestrial organic matter in the ocean is vitally important to a better understanding of the ocean carbon cycle (Hedges et al., 1997). It is estimated that rivers transport approximately $1.8 \times 10^{14} \mathrm{~g} \mathrm{yr}^{-1}$ of terrestrial particulate organic carbon (POC) to the world's oceans (Meybeck, 1982), which is around twice the rate it accumulates in ocean sediment (Keil et al., 1997, and references therein). Thus, the efficiency of riverine terrestrial particulate

Published by Copernicus Publications on behalf of the European Geosciences Union. 
organic matter (POM) burial is thought to be quite low. It is reported that $<30 \%$ Amazon riverine POM is buried in deltaic sediment (Aller et al., 1996; Keil et al., 1997). This low burial efficiency is enigmatic because most riverine POM is highly degraded soil organic matter (Hedges et al., 1994) and should presumably be recalcitrant to further degradation when delivered to the estuary and the ocean (Hedges and Keil, 1995).

Estuarine and continental shelf sediments have been long recognized as the dominant reservoir for organic carbon burial in the marine environment, and an accurate estimate of the sources of organic carbon in these sediments is essential in order to understand the transformation and the fate of terrestrial organic matter in the ocean. Although there has been abundant research attempting to tackle the questions related to the sources and fate of organic matter in coastal environments (Berner, 1982; Goni et al., 1997; Gordon and Goni, 2004; Hedges et al., 1986; Hedges and Parker, 1976; Kuwae et al., 2007; Ramaswamy et al., 2008), our understanding remains limited, and sometimes inconsistent. For example, Berner (1982) estimates that $\sim 80 \%$ of terrestrial organic carbon (TrOC) is buried in deltaic and shelf sediments, while follow-up studies suggest that a significant fraction of the TrOC may be transported to the outer shelf and slope (de Haas et al., 2002; Goni et al., 1998; Prahl et al., 1994). Recent studies based on stable and radiocarbon isotopes in combination with biomarkers reveal that the organic matter discharged into the Gulf of Mexico is of high heterogeneity (Goni et al., 1997; Gordon and Goni, 2003), and is composed of at least two groups of organic matter with contrasting source terms. One of them is of land plant origin characterized by lower $\delta^{13} \mathrm{C}$, which tends to deposit in the estuary and delta areas, and the other one is characterized by highly degraded soil-derived material with higher $\delta^{13} \mathrm{C}$, which can be transported farther offshore. As such, using end-members only with land plant $\delta^{13} \mathrm{C}$ could have underestimated the contribution of terrestrial input to the shelf systems. Gordon and Goni (2004) therefore call for a reassessment of the burial of TrOC in the ocean.

Carbohydrates occur in polymer structure forms in which monosaccharide residues are bound to each other via glycosidic bonds. They are ubiquitous in the marine environment with primary importance as both structural and storage compounds of organisms. Together with amino acids, they represent the most abundant constituents of organic matter in marine organisms, suspended and sinking particles, and dissolved organic matter (Cowie and Hedges, 1992; Hernes et al., 1996). In marine sediments, carbohydrates typically account for $3 \sim 10 \%$ of sedimentary TOC (Bergamaschi et al., 1999; Burdige et al., 2000; Kerherve et al., 2002; Skoog and Benner, 1997), and are important energy and carbon sources for various heterotrophic organisms in the sediment (Decho, 1990; Tibbles et al., 1994). Carbohydrates preserved in sediments are predominantly structural polysaccharides (Hernes et al., 1996), the compositions of which are different depend- ing upon the original sources (Cowie and Hedges, 1984a; Degens and Mopper, 1976; Hernes et al., 1996). Such a composition at the molecular level is, therefore, potentially powerful in order to distinguish between organic matter with a terrestrial or a marine source (Biersmith and Benner, 1998; Cowie and Hedges, 1984b; da Cunha et al., 2002). Moreover, the molecular composition of carbohydrates may also provide insights into the diagnosis of different organic matter biogeochemical processes (Benner and Opsahl, 2001; Keil et al., 1998). For example, during sediment diagenesis, the deoxysugars fucose (FUC) and rhamnose (RHA), and glucose (GLU) have distinct trends of variation in their relative abundance, while neutral sugar yields typically decline during organic matter decomposition (Amon and Benner, 2003; Hedges et al., 1994; Ittekkot and Arain, 1986). The application of carbohydrate indicators to source identification and to diagenesis characterization is exemplified in Table 1.

Bulk indices such as elemental and bulk isotopic composition are widely adopted to characterize the source of organic matter (Hedges and Parker, 1976; Hu et al., 2006a; Kuwae et al., 2007; Meyers, 1994; Middelburg and Nieuwenhuize, 1998; Ramaswamy et al., 2008; Yu et al., 2010). Studies using a combination of these bulk properties with molecular biomarker techniques (as the present study adopted) have been limited however. Boschker et al. (1995) apply such methodologies in Lake Gooimer, and Marchand et al. (2005) apply a similar approach to study the sediment in a mangrove system. Relatively comprehensive studies using multiple markers are reported in the Amazon system (Bernardes et al., 2004; Hedges et al., 1994). It must be pointed out that due to the complexity of the composition/source terms of organic matter and the biogeochemical evolvement they undergo in the estuarine environments, such multiple markers are important because each individual marker may be subject to limitations.

The Pearl River Estuary is a large discharge dominated estuary which, during the past thirty years, has also been subject to the high impact of anthropogenic activities associated with the fast development in the deltaic region (Dai et al., 2006, and references therein). The Pearl River provides $\sim 3.26 \times 10^{11} \mathrm{~m}^{3}$ of fresh water and $\sim 7 \times 10^{7}$ tons of sediment annually to the South China Sea (SCS) (Dai et al., 2007). About $80 \%$ of the particles discharged by the Pearl River are believed to be deposited within the Pearl River Estuary (Wai et al., 2004). Several studies have shown that the organic matter deposited in Pearl River Estuary sediments and on the adjacent SCS shelf has significant spatial variability as evidenced by bulk parameters such as TOC, total nitrogen (TN), and stable isotopic compositions $\left(\delta^{13} \mathrm{C}, \delta^{15} \mathrm{~N}\right)$. This spatial variability appears to be related to complex hydrodynamics and variable phytoplankton production (Hu et al., 2006a; Jia and Peng, 2003; Yu et al., 2010; Zhang et al., 2009). Therefore our understanding to the sources and fate of organic matter in this highly dynamic estuarine system remains very limited. No studies, for example have thus 
Table 1. Summary of carbohydrate composition and the neutral sugar ratio as indicators of organic matter sources and diagenetic state in natural samples.

\begin{tabular}{|c|c|c|c|}
\hline Parameters & Meaning & Applications & References \\
\hline$\%(\mathrm{FUC}+\mathrm{RIB})_{b}^{*}$ & $\begin{array}{l}\text { relative percentage of fu- } \\
\text { cose and ribose to total neu- } \\
\text { tral sugars }\end{array}$ & $\begin{array}{l}>10 \text { for marine plankton or bacterial; }<5 \\
\text { for vascular plant tissues }\end{array}$ & Cowie and Hedges (1984a) \\
\hline GLU/RIB* & $\begin{array}{l}\text { the ratio of glucose to ri- } \\
\text { bose }\end{array}$ & $\begin{array}{l}\text { high ratio indicating terrestrial source; } \\
\text { low ratio indicating marine source }\end{array}$ & Degens and Mopper (1976) \\
\hline MAN/XYL* & $\begin{array}{l}\text { the ratio of mannose to } x y- \\
\text { lose }\end{array}$ & $\begin{array}{l}<1 \text { for angiosperm wood, leaves and } \\
\text { grass; between } 1.5-3.5 \text { for phytoplankton; } \\
\text { between } 3.6-8.5 \text { for gymnosperm woods } \\
\text { and non woody tissues; }>6 \text { for bacteria } \\
\text { and zooplankton }\end{array}$ & Cowie and Hedges (1984a) \\
\hline$(\mathrm{FUC}+\mathrm{RHA}) /(\mathrm{ARA}+\mathrm{XYL})^{*}$ & $\begin{array}{l}\text { the ratio of }(\mathrm{fu}- \\
\text { cose }+ \text { rhamnose }) /(\text { xylose }+ \\
\text { arabinose })\end{array}$ & $\begin{array}{l}<0.5 \text { for plant-derived carbohydrates; }>2 \\
\text { for microbial carbohydrates }\end{array}$ & $\begin{array}{l}\text { Guggenberger et al. (1994); } \\
\text { da Cunha et al. (2002) }\end{array}$ \\
\hline TNS yield ${ }^{\#}$ & $\begin{array}{l}\text { total neutral sugar yield } \\
\text { normalize to total TOC }\end{array}$ & $\begin{array}{l}\text { high yield indicating fresh labile organic } \\
\text { matter; low yield indicating refractory or- } \\
\text { ganic matter }\end{array}$ & $\begin{array}{l}\text { Amon and Benner (2003); } \\
\text { Ittekkot and Arain (1986); } \\
\text { Hedges et al. (1994) }\end{array}$ \\
\hline$\%(\mathrm{FUC}+\mathrm{RHA})^{\#}$ & $\begin{array}{l}\text { relative percentage of fu- } \\
\text { cose and rhamnose to total } \\
\text { neutral sugars }\end{array}$ & $\begin{array}{l}\text { high value of } \% \text { (FUC+RHA) indicating } \\
\text { intensively diagenetic alteration }\end{array}$ & $\begin{array}{l}\text { Hedges et al. (1994); } \\
\text { Ittekkot and Arain (1986) }\end{array}$ \\
\hline Hexose/Pentose ${ }^{\#}$ & $\begin{array}{l}\text { the ratio of (glu- } \\
\text { cose }+ \text { galacose }+ \text { mannose }) / \\
\text { (xylose + arabinose) }\end{array}$ & $\begin{array}{l}\text { high ratio indicating labile organic mat- } \\
\text { ter; low ratio indicating refractory organic } \\
\text { matter }\end{array}$ & Ittekkot and Arain (1986) \\
\hline
\end{tabular}

Superscript “*” represents sources indicator; superscript "\# " represents diagenetic indicator; subscript " $b$ " indicates the parameter calculated without glucose

far been published concerning sediment organic matter with respect to the molecular composition of carbohydrates. In this paper, we present the spatial distribution of elemental (C and $\mathrm{N}), \delta^{13} \mathrm{C}$, and carbohydrate compositions of the organic matter in surface sediments collected from the upper reach of the Pearl River Estuary, Lingdingyang Bay, and the northern SCS shelf. These bulk organic geochemical parameters in combination with carbohydrate biomarkers were used to further evaluate the sources of the organic matter deposited, and to estimate the accumulation flux of the terrestrial organic matter in the areas studied. Moreover, we used carbohydrate composition and its relative abundance as biomarkers to diagnose organic matter diagenesis. This study has shown the predominance of terrestrially originating organic matter in the sediment and its generally low accumulation efficiency within the estuarine system. Such a finding is in line with findings from other estuaries, and yet it may have important implications in light of the heavy anthropogenic discharges into the Pearl River Estuary during the past thirty years.

\section{Materials and methods}

\subsection{Site description}

The Pearl River consists of three main tributaries - the North River (Beijiang), East River (Dongjiang), and West River (Xijiang), which empty into the Pearl River Estuary, and subsequently into the SCS (Guo et al., 2009, and references therein). The Pearl River Estuary consists of three sub-estuaries, namely Modaomen, Huangmaohai and Lingdingyang Bay, among which Lingdingyang Bay is the largest and traditionally regarded as being the Pearl River Estuary. This study focuses on Lingdingyang Bay, which consists of four major outlets - Humen, Jiaomen, Hongqimen and Hengmen (Fig. 1). Sediment types in the Pearl River Estuary vary, depending upon the hydrodynamics of the sedimentation environment. Overall, the western side of the estuary accumulates fine sand due to the dynamic hydrology induced by the water flow from the four outlets, while the eastern side of the estuary is dominated by silty clays and clay silts (Chen, 1994; Jia and Peng, 2003). Off the Pearl River Estuary and on the SCS shelf, sediments are characterized with clayey silt around $114.2^{\circ} \mathrm{E}$ and $21.8^{\circ} \mathrm{N}$, and with a mixture of sand/silt/clay around $115.0^{\circ} \mathrm{E}$ and $21.0^{\circ} \mathrm{N}$ (Chen, 1994). 


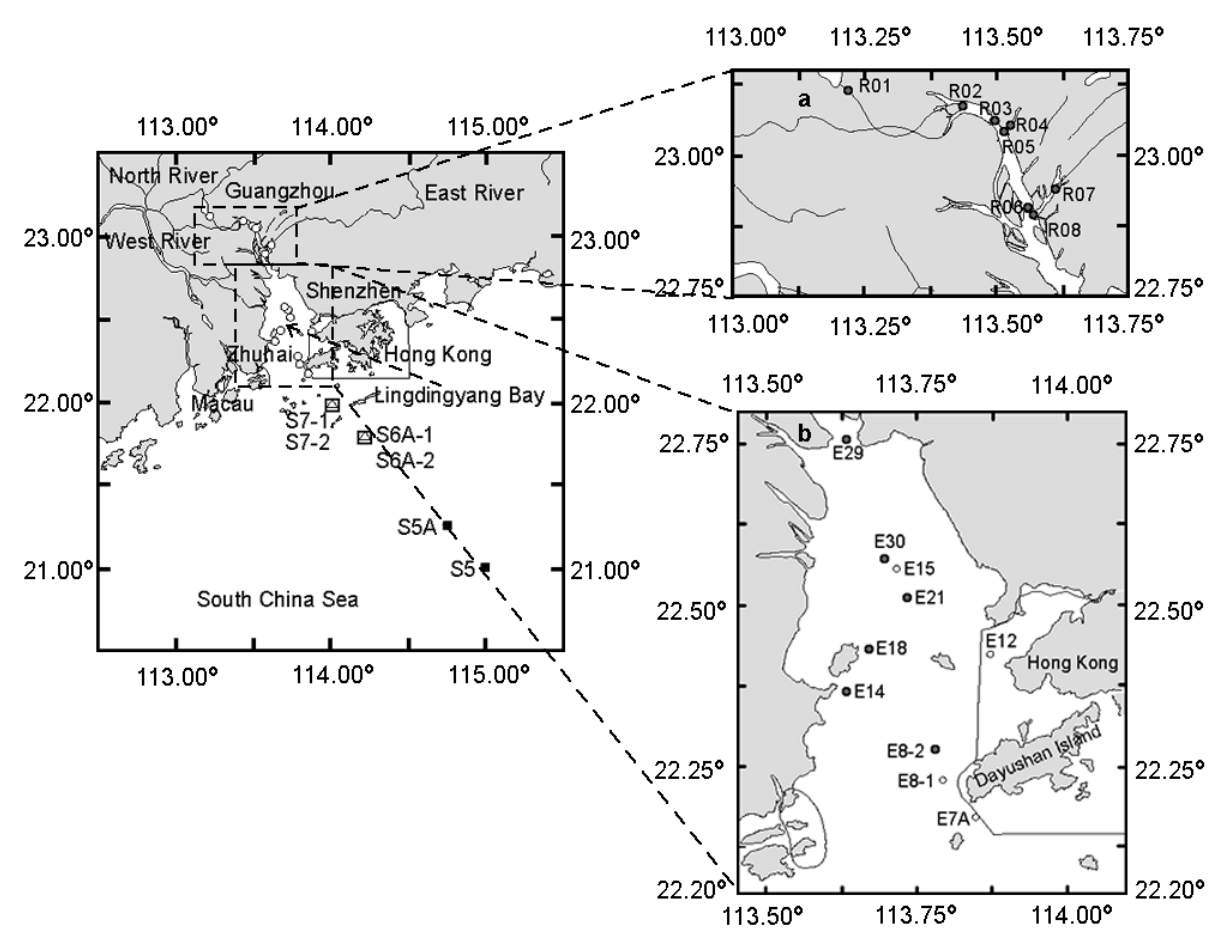

Fig. 1. Map of the Pearl River Estuary and the adjacent South China Sea (SCS) shelf showing the sampling stations: (a) in the upper reach (freshwater part) of the Pearl River Estuary; (b) in Lingdingyang Bay. The SCS shelf is defined as inner shelf (open squares) and outer shelf (closed squares) for convenience of discussion. The upper reach samples were collected in January 2005; Lingdingyang Bay and SCS shelf samples were collected in November 2002 (closed circles and squares) and May 2001 (open circle and triangles).

\subsection{Sampling}

Surface sediment samples were collected from 16 sites along the Pearl River Estuary and SCS continental shelf during two cruises on board the R/V Yanping II in May 2001 and November 2002, within which three regions have been defined for the purposes of this paper: Lingdingyang Bay, the inner shelf, and the outer shelf (Fig. 1). Eight additional surface sediments were collected in January 2005 in the fresh water part of the Pearl River Estuary and Dongjiang tributaries (hereafter referred to as the upper reach of the Pearl River Estuary) as the river input end-member (Fig. 1 and Table 2). A grab sampler was used to collect surface sediments in higher sedimentation rate areas. The sampling depth was $\sim 0-10 \mathrm{~cm}$, representing an average of $\sim 5-10$ year's sedimentation. A box sampler was used for sample collection in lower sedimentation rate areas. The top 3 or $5 \mathrm{~cm}$, representing again an average of $\sim 5-10$ year's sedimentation, was sub-sampled and regarded as surface samples. All samples were kept frozen at $-20^{\circ} \mathrm{C}$ on board upon collection, and until subsequent sample processing.

\subsection{Elemental and stable carbon isotopic composition $\left(\delta^{13} \mathrm{C}\right)$ analysis}

Sediments were oven-dried at $50{ }^{\circ} \mathrm{C}$, ground and homogenized with a pestle and mortar, then passed through a mesh sieve $(250 \mu \mathrm{m}$ in pore size). TOC and TN were detected using dry combustion with a Perkin-Elmer 2400 CHNS/O analyzer after removal of inorganic carbon. Sediment samples were soaked in $1 \mathrm{~mol} \mathrm{~L}^{-1} \mathrm{HCl}$ at room temperature for $24 \mathrm{~h}$ (Prahl et al., 1994), rinsed with Milli-Q water to remove salts, and then oven-dried at $50{ }^{\circ} \mathrm{C}$. This decarbonation method gave almost identical $\mathrm{C} / \mathrm{N}$ ratios as the de-carbonation method using concentrated $\mathrm{HCl}$ fumes for $24 \mathrm{~h}$. The relative standard deviations (RSDs) of TOC and $\mathrm{TN}$ determinations were $<5 \%$.

The stable isotopic composition of the bulk organic matter in sediments was determined using ratio mass spectrometry. Organic carbon was oxidized to $\mathrm{CO}_{2}$ using high-temperature $\mathrm{CuO}$ catalysis after removal of inorganic carbon with $1 \mathrm{~mol}$ $\mathrm{L}^{-1} \mathrm{HCl}$ (Prahl et al., 1994). The $\mathrm{CO}_{2}$ was purified using cryogenic traps in a vacuum line and collected and sealed in glass tubes; and the ratio of ${ }^{13} \mathrm{C} /{ }^{12} \mathrm{C}$ was analyzed using MAT252 mass spectrometry (Finnigan MAT, USA). $\delta^{13} \mathrm{C}$ values were expressed as the per mil $(\%)$ deviation from the Vienna Pee Dee Belemnite standard. The standard deviation of carbon isotope determination for both a working standard (the reagent grade histidine) and field samples was better than $0.2 \%$. 
Table 2. Geochemical data for surface sediments in the upper reach of the Pearl River Estuary, Lingdingyang Bay and the SCS shelf.

\begin{tabular}{|c|c|c|c|c|c|c|c|}
\hline Site & Stations & Sampling date & $\begin{array}{l}\text { Location } \\
\text { Latitude }\end{array}$ & Longitude & $\begin{array}{l}\text { Depth } \\
\text { m }\end{array}$ & Surface water salinity & Sediment type $^{\mathrm{a}}$ \\
\hline \multirow{8}{*}{ Upper reach } & R01 & Jan 2005 & 23.115 & 113.219 & 8.5 & & \\
\hline & $\mathrm{R} 02$ & Jan 2005 & 23.086 & 113.434 & 6 & & \\
\hline & $\mathrm{R} 03$ & Jan 2005 & 23.058 & 113.492 & 5 & & \\
\hline & R04 & Jan 2005 & 23.042 & 113.514 & 10 & & \\
\hline & $\mathrm{R} 05$ & Jan 2005 & 23.050 & 113.525 & 8 & & \\
\hline & R06 & Nov 2002 & 22.905 & 113.558 & 5 & & \\
\hline & R07 & Jan 2005 & 22.943 & 113.614 & 7.5 & & \\
\hline & R08 & Jan 2005 & 22.891 & 113.573 & 12.5 & & \\
\hline \multirow{10}{*}{ Lingdingyang Bay } & E7A & May 2001 & 22.170 & 113.852 & 16 & 25.31 & mixture of sand and clay \\
\hline & E8-1 & May 2001 & 22.228 & 113.797 & 23 & 8.5 & mixture of sand and clay \\
\hline & $\mathrm{E} 8-2$ & Nov 2002 & 22.264 & 113.785 & 14.5 & 26.46 & silty clay \\
\hline & E12 & May 2001 & 22.423 & 113.876 & 12 & 19.5 & - \\
\hline & E14 & Nov 2002 & 22.365 & 113.637 & 9.5 & 11.77 & fine sand \\
\hline & E18 & Nov 2002 & 22.432 & 113.674 & - & 1.82 & find sand \\
\hline & E15 & May 2001 & 22.555 & 113.721 & 9 & 4.87 & mixture of sand and clay \\
\hline & E21 & Nov 2002 & 22.510 & 113.737 & 8.5 & 9.5 & mixture of sand and clay \\
\hline & E30 & Nov 2002 & 22.572 & 113.699 & 10 & 2.6 & mixture of sand and clay \\
\hline & E29 & Nov 2002 & 22.752 & 113.639 & 12 & 0.6 & sandy clay \\
\hline \multirow{4}{*}{ Inner Shelf } & S6A-1 & May 2001 & 21.798 & 114.205 & 45 & 32.93 & clayer silt \\
\hline & S6A-2 & Nov 2002 & 21.801 & 114.208 & 45 & 33.26 & clayer silt \\
\hline & S7-1 & May 2001 & 22.000 & 113.996 & 33 & 31.85 & silty clay \\
\hline & S7-2 & Nov 2002 & 22.001 & 113.995 & 35 & 32.63 & silty clay \\
\hline \multirow{2}{*}{ Outer Shelf } & S5 & Nov 2002 & 21.002 & 114.99 & 100 & 33.61 & sandy clay \\
\hline & S5A & Nov 2002 & 21.258 & 114.747 & 80 & 33.55 & sandy clay \\
\hline
\end{tabular}

a Sediment types were cited from the previous studies (Chen 1994; Jia and Peng, 2003).

\subsection{Carbohydrate analysis}

\subsubsection{Individual sugar analysis}

Analysis of carbohydrates is generally initiated with a hydrolysis step that yields a pool of monomers (monosaccharides), which are subsequently detected by either colorimetric or chromatographic methods. Hydrolysis is, therefore, a critical process in the determination of sugar composition. Various hydrolysis techniques have been employed, depending on the type of sample (Panagiotopoulos and Semperé, 2005, and references therein). We chose "mild" hydrolysis, using $4.0 \mathrm{~mol} \mathrm{~L}^{-1}$ trifluoroacetic acid (TFA) to release monosaccharide from the marine surface sediments. Approximately $0.5 \mathrm{~g}$ dried sediment was weighed into a precombusted $50 \mathrm{~mL}$ glass tube with a Teflon-lined cap. A $4.0 \mathrm{~mol} \mathrm{~L}^{-1}$ TFA solution $(5.0 \mathrm{~mL})$ was added to each tube, after which the sample was hydrolyzed at $105^{\circ} \mathrm{C}$ with magnetic stirring for $4 \mathrm{~h}$. The comparison between this "mild" hydrolysis method and the "strong" hydrolysis method is presented in Sect. 2.5.
Upon hydrolysis a certain amount of adonitol (Sigma Co.) was added to the hydrolysate as a gas chromatography (GC) internal standard. The solution was completely homogenized, and then centrifuged for $20 \mathrm{~min}$ at $3000 \mathrm{rpm}$ and the supernatant was collected in a $100 \mathrm{~mL}$ pear-shaped flask. The solution was then rotary evaporated to remove TFA at $\leq 50^{\circ} \mathrm{C}$. The dried hydrolysate was redissolved in $\sim 2 \mathrm{~mL}$ Milli-Q water, and the solution $(\mathrm{pH}=2-3)$ was then run through a $\sim 25 \mathrm{~mL}$ cation/anion mixed column at a flow rate of $0.8-1.0 \mathrm{~mL} \mathrm{~min}^{-1}$ to desalt. The ion exchange column was packed with mixed $(1: 1 \mathrm{v} / \mathrm{v})$ cation $001 \times 7(732$, Lvyin Co., China) and anion resins $201 \times 7$ (717, Lvyin Co., China) and the sugar fraction was eluted with at least three bed volumes of Milli-Q water. The deionized hydrolysate was again rotary evaporated to dryness.

We preconditioned the resins as follows: first, the resins were washed thoroughly with Milli-Q water, and then soaked in Milli-Q water for $12 \mathrm{~h}$. After the water was removed, the resins were soaked in ethanol for $4 \mathrm{~h}$ to remove any alcoholsoluble substances. After the ethanol was washed out, the cationic resins were transformed into hydrogen-type resins 


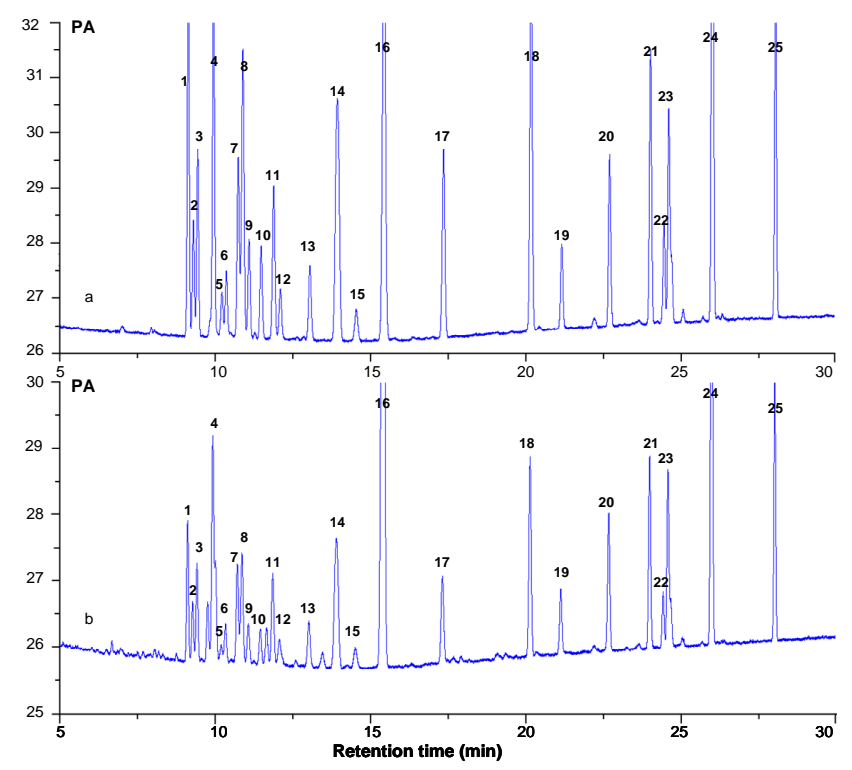

Fig. 2. Gas chromatograms of TMS derivatives of monosaccharides. (a) a standard mixture; (b) a hydrolysate from the Pearl River Estuary sediment. Twenty five peaks are identified, and the peaks with “*” are isomers used for quantification: 1. LYX1*; 2. ARA1; 3. ARA2*; 4. LYX2, RHA1, XYL1; 5. RIB1; 6. FUC1; 7. ARA3; 8. RIB2, LYX3; 9. LYX4; 10. RIB3*; 11. FUC2*; 12. ARA4; 13. RHA2*; 14. XYL2, FUC3; 15. FUC4; 16. Adonitol; 17. XYL3*; 18. MAN1*; 19. GAL1; 20. GAL2*; 21. GLU1; 22. MAN2; 23. GAL3; 24. Sorbitol; 25. GLU2*. (LYX - lyxose; ARA - arabinose; RIB - ribose; RHA - rhamnose; FUC - fucose; XYL - xylose; MAN - mannose; GAL - galactose; GLU - glucose). If there are several isomers for a compound, they are named with different numbers according to the retention time of the isomers. For example, glucose has two isomers, namely $\alpha$-glucose and $\beta$-glucose. The isomer with short retention time is named GLU1, and the other one is named GLU2.

by soaking in $\sim 1 \mathrm{~mol} \mathrm{~L}^{-1} \mathrm{HCl}$ solution for $4 \mathrm{~h}$. Finally, the resins were washed with Milli-Q water until the $\mathrm{pH}=5-6$. The anionic resins were then soaked in $\sim 1 \mathrm{~mol} \mathrm{~L}^{-1} \mathrm{NaOH}$ solution for $4 \mathrm{~h}$ to transform them into $\mathrm{OH}$-type resins, followed by Milli-Q water wash to $\mathrm{pH}=7-8$.

The equilibration and derivatization of sugar were based on the method of Cowie and Hedges (1984b). Briefly, the deionized dried sample was dissolved in double distilled pyridine. An absolute recovery standard (sorbitol) (Sigma Co.) was added to the solution followed by an equal volume of $0.4 \%(\mathrm{w} / \mathrm{v}) \mathrm{LiClO}_{4}$ in pyridine. The sugar anomers were equilibrated at $60^{\circ} \mathrm{C}$ for $48 \mathrm{~h}$ and derivatized with Regisil reagent (bis (trimethylsilyl) trifluoroacetamide $+1 \%$ trimethylchorosilane) for $20 \mathrm{~min}$ at $60^{\circ} \mathrm{C}$ to form trimethylsilyl ether (TMS) derivatives. Analysis of individual sugars was carried out using a Hewlett-Packard (HP) 6890 gas chromatograph equipped with a $30 \mathrm{~m}$ by $0.32 \mathrm{~mm}$ i.d. fused-silica capillary column (HP-5) with a flame ionization detector (FID). Both the injection port and the FID were maintained at a constant temperature of $300^{\circ} \mathrm{C}$. The injection volume was $1 \mu \mathrm{L}$ with a split of $5: 1$. Hydrogen was employed as the carrier gas at $\sim 1.5 \mathrm{~mL} \mathrm{~min}^{-1}$ in a constant flow mode. Column temperature was programmed from $150^{\circ} \mathrm{C}$ after an initial delay of $15 \mathrm{~min}$, then increasing at $3{ }^{\circ} \mathrm{C} \mathrm{min}^{-1}$ to $200^{\circ} \mathrm{C}$, and after that increasing at $15^{\circ} \mathrm{C} \mathrm{min}^{-1}$ to $280^{\circ} \mathrm{C}$ and holding for $5 \mathrm{~min}$. Under these conditions the best peak resolution could be obtained, and quantification on the basis of a single clearly resolved peak for each sugar was made possible (Fig. 2). Each monosaccharide was identified using its relative retention time compared to the internal standard adonitol, and quantified using an internal standard. Total neutral sugar (TNS) concentration was calculated as the sum of the individual sugars, and normalized to TOC (in units of mg neutral sugar $\left.\left(100 \mathrm{mg} \mathrm{OC}^{-1}\right)\right)$.

\subsubsection{Total carbohydrate}

Total carbohydrate (TCHO) concentrations in the sediments were determined using a method modified from the phenolsulfuric acid (PSA) assay (Miyajima et al., 2001). Briefly, carbohydrates were first hydrolyzed to individual monosaccharides using $4.0 \mathrm{~mol} \mathrm{~L}^{-1} \mathrm{TFA}$ following the same hydrolysis protocol as for the individual sugar analysis. The hydrolysate was centrifuged and the supernatant was collected and diluted. The dilution was used to analyze TCHO following this PSA procedure. The TCHO yields reported here were based on standard curves constructed from GLU standards and presented in units of $\mathrm{mg}$ carbohydrate $(100 \mathrm{mg}$ $\mathrm{OC}^{-1}$.

\subsection{Quality controls and assessment}

In order to control the quality of our elemental and isotope analysis, we chose three sediments from the west Pacific as our working reference material for quality control on a daily basis during the sample preparation and analysis. These Pacific sediments are reported to have very uniform $\mathrm{C} / \mathrm{N}$ ratios and organic carbon isotopic composition, identical to the typical values of marine phytoplankton (e.g., Goering et al., 1990). Our measured carbon isotope compositions of these sediments ranged from -20.2 to $-20.9 \%$, which agreed well with the reported value of $-20.8 \pm 0.8 \%$ (Goering et al., 1990). The standard deviation of $\delta^{13} \mathrm{C}$ during our long term sample analysis was better than $0.2 \%$.

A complete description of the QA/QC measures and the results for the measurement of monosaccharide compositions has been published (He et al., 2003). The RSD of analysis was $0.1-14 \%$ for nine monosaccharides. A spiked recovery (sample + spike) was $77-115 \%$ with an RSD of $1.8-11 \%$, and the detection limits of the TMS-monosaccharide ranged from $0.02-0.06 \mathrm{mg} \mathrm{L}^{-1}$ with a signal to noise ratio of 3 . The recovery of the internal standard, adonitol, was $79.8 \%(n=6$, $\mathrm{RSD}=5.2 \%$ ) throughout the sample processing procedure. 

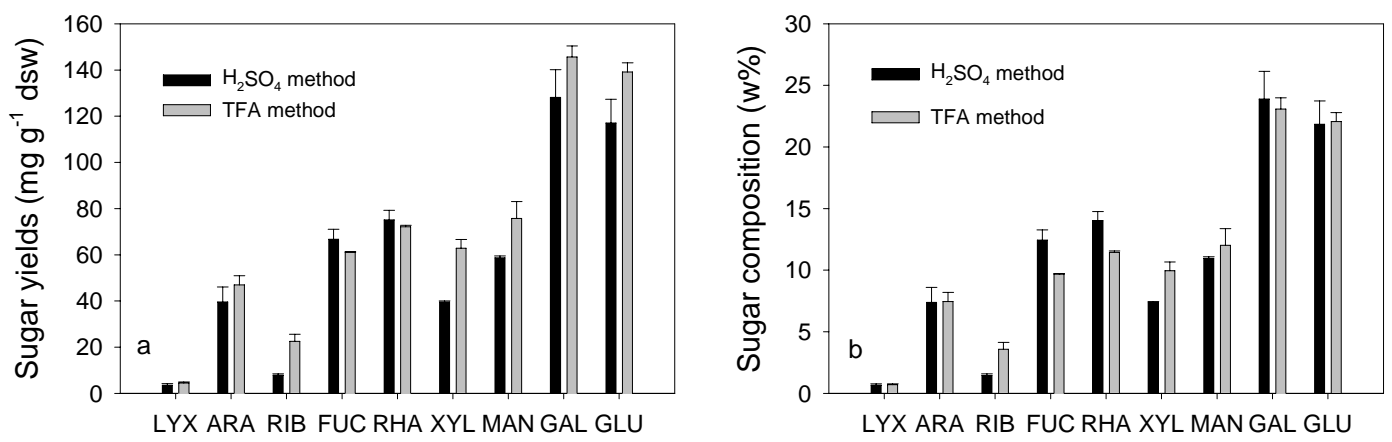

Fig. 3. Monosaccharide yields ( $\mathrm{mg} \mathrm{g}^{-1}$ dry sediment weight) (a) and neutral sugar compositions (wt \%) (b) from surface sediments using different hydrolytic procedures. The error bars represent the standard deviation $(n=5)$.

Table 3. Organic geochemical data for surface sediments, and the fraction of terrigenous organic matter contribution to sediment TOC in the upper reach of the Pearl River Estuary, Lingdingyang Bay and the SCS shelf.

\begin{tabular}{|c|c|c|c|c|c|c|c|}
\hline Site & Stations & TOC (\%) & $\mathrm{TN}(\%)$ & Atomic $\mathrm{C} / \mathrm{N}$ & $\delta^{13} \mathrm{C}(\% \circ)$ & $f_{\mathrm{t}}(\%)$ & $F_{\mathrm{t}}(\%)$ \\
\hline \multirow{9}{*}{ Upper reach } & R01 & 4.41 & 0.23 & 22.4 & -24.9 & & \\
\hline & R02 & 0.95 & 0.08 & 13.9 & -26.1 & & \\
\hline & R03 & 1.97 & 0.18 & 12.9 & -25.5 & & \\
\hline & R04 & 0.95 & 0.07 & 15.8 & -24.3 & & \\
\hline & R05 & 0.60 & 0.06 & 11.7 & -23.1 & & \\
\hline & R06 & 1.34 & 0.13 & 11.8 & -25.5 & & \\
\hline & R07 & 1.52 & 0.13 & 13.6 & -25.4 & & \\
\hline & R08 & 1.14 & 0.10 & 13.3 & -24.6 & & \\
\hline & Mean \pm sd & $1.21 \pm 0.45$ & $0.11 \pm 0.04$ & $13.3 \pm 1.4$ & $-24.9 \pm 1.0$ & & \\
\hline \multirow{11}{*}{ Lingdingyang Bay } & E7A & 0.67 & 0.07 & 10.8 & -22.3 & 55 & 72 \\
\hline & E8-1 & 0.67 & 0.06 & 13.0 & -23.6 & 88 & 94 \\
\hline & E8-2 & 0.84 & 0.08 & 11.9 & -23.1 & 71 & 83 \\
\hline & E12 & 0.86 & 0.12 & 8.4 & -24.9 & 38 & 56 \\
\hline & E14 & 1.32 & 0.15 & 10.5 & -23.5 & 57 & 74 \\
\hline & E18 & 1.11 & 0.13 & 9.7 & -25.1 & 56 & 72 \\
\hline & E15 & 1.24 & 0.12 & 12.3 & -25.0 & 88 & 94 \\
\hline & E21 & 0.93 & 0.10 & 10.7 & -23.3 & 58 & 74 \\
\hline & E30 & 1.12 & 0.12 & 11.4 & -23.4 & 67 & 81 \\
\hline & E29 & 1.26 & 0.14 & 10.4 & -24.5 & 61 & 77 \\
\hline & mean $\pm \mathrm{sd}$ & $1.0 \pm 0.22$ & $0.11 \pm 0.03$ & $10.9 \pm 1.3$ & $-23.9 \pm 1.0$ & $64 \pm 15$ & $78 \pm 11$ \\
\hline \multirow{5}{*}{ Inner Shelf } & S6A-1 & 0.66 & 0.11 & 8.4 & -21.5 & 23 & 38 \\
\hline & S6A-2 & 0.91 & 0.13 & 8.1 & -21.4 & 20 & 33 \\
\hline & S7-1 & 0.79 & 0.13 & 6.9 & n.a. & n.a & n.a. \\
\hline & S7-2 & 0.84 & 0.12 & 7.9 & -21.5 & 18 & 31 \\
\hline & mean \pm sd & $0.80 \pm 0.10$ & $0.12 \pm 0.01$ & $7.8 \pm 0.6$ & $-21.5 \pm 0.04$ & $20 \pm 3$ & $34 \pm 4$ \\
\hline \multirow{3}{*}{ Outer Shelf } & S5 & 0.54 & 0.10 & 6.6 & -21.3 & 3.2 & 6.4 \\
\hline & S5A & 0.62 & 0.11 & 6.5 & -21.4 & 2.3 & 4.7 \\
\hline & mean $\pm \mathrm{sd}$ & $0.58 \pm 0.06$ & $0.10 \pm 0.01$ & $6.5 \pm 0.09$ & $-21.4 \pm 0.1$ & $2.8 \pm 0.6$ & $5.5 \pm 1.2$ \\
\hline
\end{tabular}

$f_{\mathrm{t}}=$ the fraction of terrigenous organic nitrogen; $F_{\mathrm{t}}=$ the fraction of terrigenous organic carbon; n.a. = no analysis; the mean values of the parameters in the upper reach of the Pearl River Estuary were calculated with the exclusion of the highly polluted station R01.

Given the primary importance of hydrolysis in the determination of individual sugars, we compared the $4.0 \mathrm{~mol} \mathrm{~L}^{-1}$ TFA hydrolysis method with the strong sulfuric acid method
(Cowie and Hedges, 1984b). The latter was recommended for terrestrial samples rich in $\alpha$-cellulose. Strong hydrolysis may also be used for marine samples containing "refractory" 


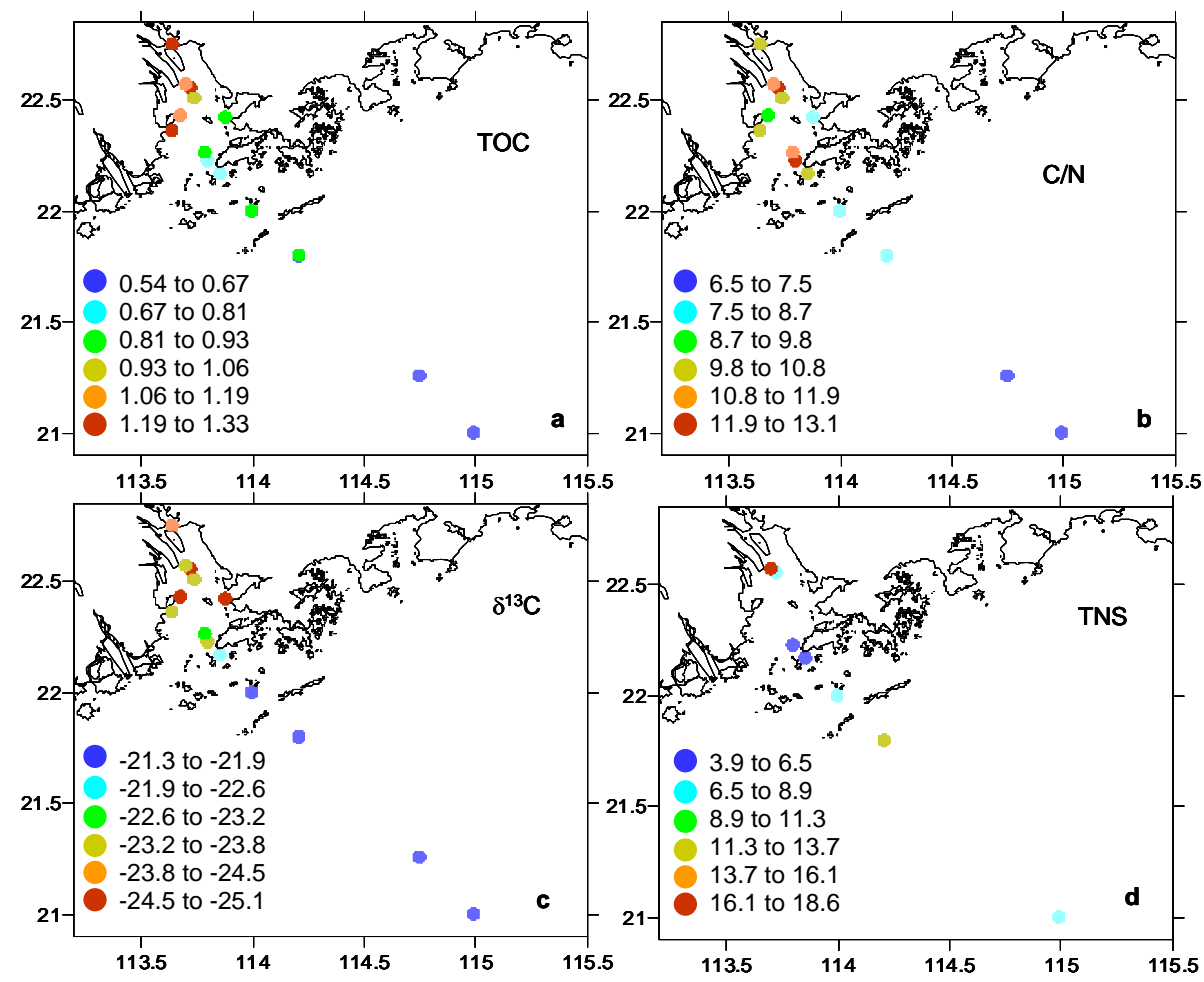

Fig. 4. Spatial distribution of TOC (\%) (a), C/N ratios (b), $\delta^{13} \mathrm{C}(\% \circ)(\mathbf{c})$ and TNS (mg neutral sugar (100 mg OC) $\left.)^{-1}\right)(\mathbf{d})$ in the surface sediment in Lingdingyang Bay and on the shelf of the South China Sea.

structural polysaccharides (Kerherve et al., 2002; Pakulski and Benner, 1992). Strong hydrolysis is usually performed in two steps. Samples were treated with $12 \mathrm{~mol} \mathrm{~L}^{-1}$ sulfuric acid at room temperature, after which the acid was diluted to $1.2 \mathrm{~mol} \mathrm{~L}^{-1}$ and heated in a boiling water bath with stirring. The individual neutral monosaccharide yields and their relative composition in the same sediment samples using these two hydrolysis methods are presented in Fig. 3. The results showed that the TFA hydrolysis method gave comparable yields of lyxose (LYX), arabinose (ARA), FUC, RHA, galactose (GAL) and GLU, but significantly higher yields of xylose (XYL) and ribose (RIB), than those of the strong $\mathrm{H}_{2} \mathrm{SO}_{4}$ hydrolysis method (Fig. 3a). Previous studies also find that hydrolysis with $2 \mathrm{~mol} \mathrm{~L}^{-1}$ TFA for spruce holocellulose and with $4 \mathrm{~mol} \mathrm{~L}^{-1}$ TFA for soil samples give higher yields of all monosaccharides (except GLU) than $12 \mathrm{~mol} \mathrm{~L}^{-1}$ $\mathrm{H}_{2} \mathrm{SO}_{4}$ (Amelung et al., 1996; Fengel and Wegener, 1979). Pentoses are reported to be more fragile than hexoses and are partially destroyed after strong hydrolysis, especially RIB (Mopper, 1977; Panagiotopoulos and Sempéré, 2005). The higher yields of XYL and RIB are likely to be due to less destruction of these monosaccharides during mild hydrolysis. As for sugar compositions (wt \%), TFA hydrolysis gave a comparable relative abundance for all monosaccharides (except for a significantly higher percentage of RIB) than those of the strong $\mathrm{H}_{2} \mathrm{SO}_{4}$ hydrolysis method (Fig. 3b).
Strong hydrolysis generally gives a higher yield of GLU due to the more efficient cleavage of $\alpha$-cellulose. However, for our sediment samples, strong hydrolysis did not give a higher yield of GLU. This result was probably due to the fact that our sediment samples for the comparison experiments contained a low content of $\alpha$-cellulose because the sediment samples were collected from the inner shelf (station S7-1), which contained no more than $31 \%$ terrestrial organic matter (see discussion below). It should be noted that TFA hydrolysis might underestimate the GLU content in the upper reach of the estuary when compared to strong hydrolysis, if the sediment samples contained a large amount of $\alpha$-cellulose.

\subsection{Statistical analysis}

Principal component analysis (PCA) was employed to identify the sources of carbohydrate. Nine monosaccharide composition (wt \%) dataset for 14 stations (including upper reach, estuary, and SCS shelf) were used for analysis. Values less than the detection limit were substituted by one half of the detection limit (Harrison et al., 1996; Buhamra et al., 1998). The SPSS 11.0 software package was used for data treatment. 


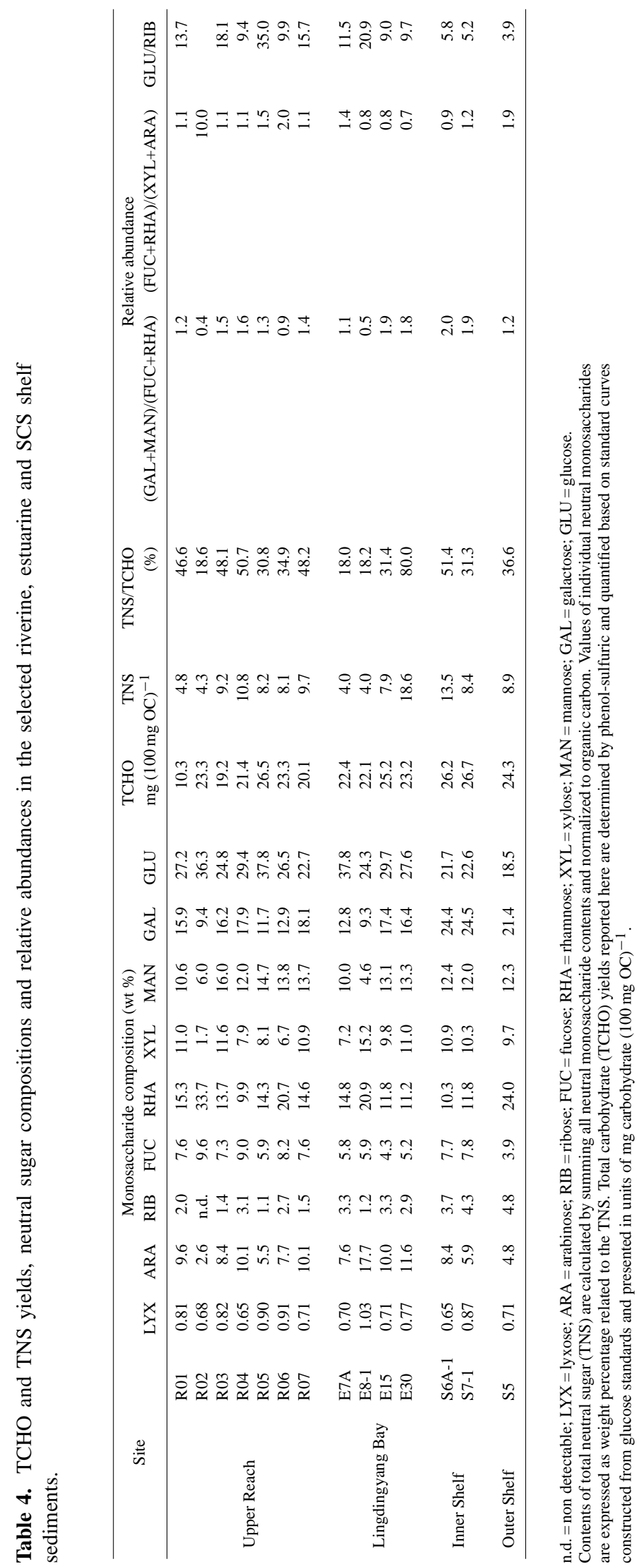




\section{Results}

\subsection{Bulk characteristics of the sediments}

TOC and TN contents of the eight riverine sediments analyzed in this study spanned a range from $0.60 \%$ to $4.41 \%$ and $0.06 \%$ to $0.23 \%$ by weight (Table 3 ), reflecting the wide variety of sedimentary environments and sediment textures. Atomic $\mathrm{C} / \mathrm{N}$ ratios ranged from 11.7 to 22.4 (Table 3). The highest $\mathrm{C} / \mathrm{N}$ ratio along with the highest content of TOC and TN was observed at station R01 near Guangzhou where wastewater discharge containing large amounts of organic matter and ammonia occurred (He et al., 2010). The concentrations of TOC and TN were highly correlated in the sediments collected from the upper reach of the estuary except for the highly polluted station R01, indicating the same origin of TOC and TN. The linear regression equation was as follows:

$\mathrm{TN} \%=0.092 \mathrm{TOC} \%-0.004, R^{2}=0.96$

The intercept of the regression line was $\sim 0$, suggesting that most of the nitrogen measured by our method was related to sedimentary organic carbon and probably in the organic form (Hedges et al., 1986). The slope of the regression line indicated a best-fit atomic $\mathrm{C} / \mathrm{N}$ ratio of 12.7 , suggesting that most of the TOC in the upper reach of the Pearl River Estuary was attributable to soil derived organic matter. Soil organic matter tends to have a lower $\mathrm{C} / \mathrm{N}$ ratio (8-14) than plant organic matter $(>20)$ due to the retention of nitrogen by microbes during organic matter remineralization in soils (Hedges and Oades, 1997). The $\delta^{13} \mathrm{C}$ values of $-23.1 \%$ $~-26.1 \%$ with an average of $-24.9 \pm 1.0 \%$ (when excluding station R01) also closely matched soil attributes (Prahl et al., 1994), implying that the bulk organic carbon preserved in the river sediments was mostly land-derived organic matter. This conclusion seemed surprising, since there were other potentially significant sources of organic carbon for these sediments, including phytoplankton production and the sewage input in the upper reach of the estuary. We attributed this to selective degradation of autochthonous and sewage-derived POM, resulting in dominant preservation of stable $\mathrm{TrOC}$ in the sediments. High Chl- $a$ concentration $\left(>20 \mu \mathrm{g} \mathrm{L}^{-1}\right)$ coupled with high bacterial oxygen consumption rates $\left(2.8-5.8 \mu \mathrm{mol} \mathrm{O}_{2}\right.$ $\mathrm{L}^{-1} \mathrm{~h}^{-1}$ ) in the water column in this area may lend additional evidence for the selective removal of autochthonous labile POM in the water column or at the sediment water interface (He et al., 2010). Compared to the $\delta^{13} \mathrm{C}$ and $\mathrm{C} / \mathrm{N}$ ratio of the in situ phytoplankton $\left({ }^{13} \mathrm{C}\right.$ : $-31.2 \%$ o to $-25.8 \%$, $\mathrm{C} / \mathrm{N}$ ratio: 6.5 to 8.4$)$ and $\mathrm{POM}$ in sewage $\left(\delta^{13} \mathrm{C}:-25.9 \%\right.$ o to $-22.8 \%$, $\mathrm{C} / \mathrm{N}$ ratio: 5.8 to 7.1, Dai et al., unpublished data), sediment TOC had isotopic compositions $\left(\delta^{13} \mathrm{C}\right.$ : $-26.1 \%$ o to $-23.1 \%$ ) between those of phytoplankton and sewage derived POM but significantly higher $\mathrm{C} / \mathrm{N}$ ratios $(\mathrm{C} / \mathrm{N}$ : $11.7-$ 22.4). Such an elevation in the $\mathrm{C} / \mathrm{N}$ ratio of the sediments suggested again that the efficiency with which phytoplank- ton and sewage-derived POM was preserved in the sediment was low due to selective degradation.

In the Pearl River Estuary and on the SCS shelf, both TOC contents and $\mathrm{C} / \mathrm{N}$ ratios showed a similar trend. Relatively high TOC was observed along the west side of Lingdingyang Bay, which decreased gradually offshore (Fig. 4a), with a mean value of $1.00 \pm 0.22 \%$ in Lingdingyang Bay decreasing to $0.58 \pm 0.06 \%$ on the outer shelf (Table 3 ). Similarly the atomic $\mathrm{C} / \mathrm{N}$ ratio (Fig. 4b), which ranged from 8.4-13.0 in Lingdingyang Bay to 6.9-8.4 on the inner shelf, and to 6.5-6.6 on the outer shelf (Table 3), showed the relative enrichment of nitrogen seawards. Meanwhile, $\delta^{13} \mathrm{C}$ became progressively heavier from the estuary $(-23.9 \pm 1.0 \%$ o $)$ to the inner shelf $(-21.5 \pm 0.04 \%$ o $)$ and outer shelf $(-21.4 \pm 0.1 \%$ o sediments (Fig. 4c, Table 3), indicating an increase in the proportion of marine organic matter towards the outer shelf, It is interesting that at two stations (stations E12 and E8-1) we observed "abnormal" $\mathrm{C} / \mathrm{N}$ ratios and $\delta^{13} \mathrm{C}$ values with a remarkably depleted $\delta^{13} \mathrm{C}$ of $-24.9 \%$ at station E12, and the highest $\mathrm{C} / \mathrm{N}$ ratio among all samples of 13.0 at station E8-1, the reason for which is presented in the discussion section. Note that station E12 is located at the east side of the Bay, whereas station E8-1 is located near Dayushan Island.

\subsection{Carbohydrate composition of the sediments}

Samples from the upper reach of the estuary were also analyzed for TCHO and individual neutral carbohydrate. Nine major neutral sugars in the sediment samples were identified and quantified (Fig. 2a, b). TCHO yields, TNS yields, individual neutral carbohydrate composition (wt $\%$ of individual aldose relative to the total aldoses), and the ratios of individual sugars are reported in Table 4.

TNS yields of the sediments in the upper reach of the Pearl River Estuary ranged from 4.3 to $10.8 \mathrm{mg}$ (100 mg OC $)^{-1}$ with a mean of $7.9 \pm 2.4 \mathrm{mg}(100 \mathrm{mg} \mathrm{OC})^{-1}$, which were much lower than the TCHO yields analyzed using the PSA method for the same sediment samples (10.3-26.5 mg $\left(100 \mathrm{mg} \mathrm{OC}^{-1}\right.$, Table 4$)$. The TNS yields observed here were consistent with the values reported in other riverine sediments (Jennerjahn and Ittekkot, 1999). The most abundant neutral sugar was GLU $(29.2 \pm 5.7 \%)$, followed by RHA $(17.5 \pm 7.8 \%)$, GAL $(14.6 \pm 3.3 \%)$ mannose (MAN, $12.4 \pm 3.3 \%), \mathrm{XYL}(8.3 \pm 3.4 \%)$, FUC $(7.9 \pm 1.2 \%)$ and ARA $(7.7 \pm 2.8 \%)$. RIB and LYX were minor components and present only in small amounts, $2.0 \pm 0.8 \%$ and $0.8 \pm 0.1 \%$, respectively (Table 4 ).

Surface sediments of seven stations (E7A, E8-1, E15, E30, S6A-1 S7-1, and S5) along the salinity gradient from the Pearl River Estuary to the SCS shelf were also chosen to analyze TCHO and individual neutral sugars. At these selected stations, TCHO yields generally followed TOC concentrations and ranged from 22.1 to $26.7 \mathrm{mg}(100 \mathrm{mg} \mathrm{OC})^{-1}$ (Table 4), being slightly depleted downstream Lingdingyang Bay (stations E7A and E8-1) and enhanced in the inner shelf 


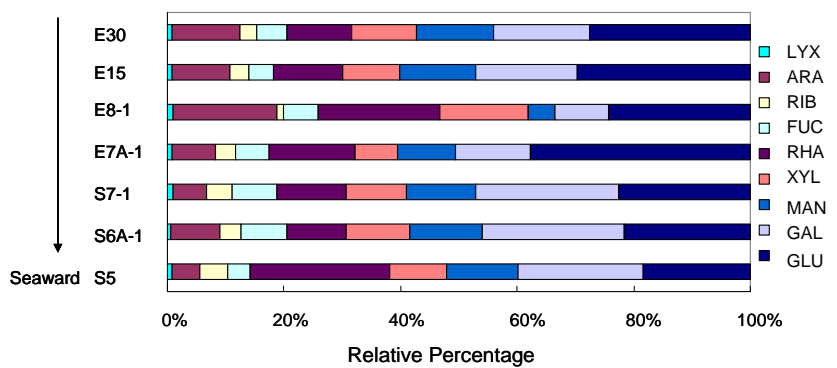

Fig. 5. Normalized distribution of monosaccarides in surface sediments collected from Lingdinyang Bay and the shelf of the South China Sea.

(stations S7-1 and S6A-1). TNS yields ranged from 4.0 to $18.6 \mathrm{mg}(100 \mathrm{mg} \mathrm{OC})^{-1}$, which were similar to the typical values reported for coastal surface sediments $(5-20 \mathrm{mg}$ $\left(100 \mathrm{mg} \mathrm{OC}^{-1}\right)$ (Bergamaschi et al., 1997; Burdige et al., 2000; Cowie and Hedges, 1984a; Kerherve et al., 2002). The highest yield of TNS was found in the vicinity of the river outlet, while the lowest yield was found near Dayushan Island (Fig. 4d). The contribution of TNS to TCHO varied substantially, ranging 18-80\%. High variability of TNS/TCHO $(18-47 \%)$ was also reported elsewhere in the Mandovi Estuary sediment with more than half of the bulk carbohydrates were not neutral aldoses (Khodse et al., 2008). A probable reason which may explain this difference between TNS and TCHO is that carbohydrates determined by the PSA method include neutral monosaccharides and their methyl derivatives including uronic acids (Dubois et al., 1956). Moreover, the differences may also be due to structural changes of individual aldoses incorporated into refractory DOC molecules that can still be characterized by the PSA method but not by the GC method (Khodse et al., 2008).

The neutral sugar composition of the Pearl River Estuary and SCS shelf showed a high spatial variation (Fig. 5). GLU, GAL and RIB were enhanced seawards, whereas ARA deceased seawards except at stations E8-1 and E7A (Fig. 5). Station E8-1 was characterized by the highest abundance of ARA and RHA, and the lowest abundance of GAL, MAN and BIB, while station E7A had the highest abundance of GLU and the lowest abundance of XYL. Except for these two stations, the abundance of MAN and XYL was similar at other stations (Fig. 5). LYX was the least abundant, and accounted for no more than $1 \%$ in all samples (Fig. 5, Table 4). On average, GLU was the major monosaccharide $(26.0 \pm$ $6.4 \%)$, which was followed by GAL (18.0 $\pm 5.8 \%)$, RHA $(15.0 \pm 5.4 \%)$, MAN $(11.1 \pm 3.1 \%)$, XYL $(10.6 \pm 2.4 \%)$, ARA $(9.4 \pm 4.3 \%)$, FUC $(5.8 \pm 1.5 \%), \operatorname{RIB}(3.3 \pm 1.2 \%)$ and LYX $(0.8 \pm 0.1 \%)$ (Table 4$)$. Station E7A and E8-1 had the lowest yields of TNS $\left(4.0 \mathrm{mg}(100 \mathrm{mg} \mathrm{OC})^{-1}\right)$ with distinct differences in carbohydrate composition (Fig. 5 and Table 4), suggesting that these carbohydrates might have undergone extensive biodegradation and/or biotransformation.

\section{Discussion}

\subsection{Terrestrial organic carbon contribution to sedi- ments from the Pearl River Estuary and SCS shelf}

The sources of sediment organic matter can be indicated by the $\mathrm{C} / \mathrm{N}$ ratio and the carbon isotopic composition (Hayes, 1993; Middelburg and Nieuwenhuize, 1998). In order to determine the potential sources for the sedimentary organic matter, a simple mixing model based on $\mathrm{C} / \mathrm{N}$ ratio and $\delta^{13} \mathrm{C}$ of the sediment was used to estimate the contribution of terrigenous organic matter to the sediment samples from the Pearl River Estuary and SCS shelf. This two end-member mixing model has been successfully used to estimate relative contribution of organic carbon from terrestrial and marine sources in estuarine and ocean margin systems (Cai et al., 1988; Hedges and Parker, 1976; Liu et al., 2007; Prahl et al., 1994). It was assumed that our sedimentary system received terrigenous organic matter input from a single riverine source, followed by mixing with marine organic matter in the estuary. This postulate was probably reasonable in this discharge dominated estuary. Then both the $\mathrm{C} / \mathrm{N}$ ratio $(R)$ and the $\delta^{13} \mathrm{C}$ value $(\delta)$ of the mixture may be expressed as a function of the terrigenous organic nitrogen fraction $\left(f_{\mathrm{t}}\right)$ as follows:

$R=R_{\mathrm{t}} f_{\mathrm{t}}+\left(1-f_{\mathrm{t}}\right) R_{\mathrm{m}}$

$\delta=\left(f_{\mathrm{t}} R_{\mathrm{t}} \delta_{\mathrm{t}}+\left(1-f_{\mathrm{t}}\right) R_{\mathrm{m}} \delta_{\mathrm{m}}\right) / R$

where $R_{\mathrm{m}}$ and $R_{\mathrm{t}}$ represent the marine and terrestrial C/N ratios; and $\delta_{\mathrm{m}}$ and $\delta_{\mathrm{t}}$ represent the marine and terrestrial $\delta^{13} \mathrm{C}$ values. It is noted that the fraction of terrestrial nitrogen $\left(f_{\mathrm{t}}\right)$ was used in Eqs. (2) and (3) so as to match the $\mathrm{C} / \mathrm{N}$ ratio to make the calculation more straightforward (Liu et al., 2007). The terrestrial organic nitrogen fraction was then transformed into the terrestrial carbon fraction $\left(F_{\mathrm{t}}\right)$ using Eq. (4):

$F_{\mathrm{t}}=R_{\mathrm{t}} f_{\mathrm{t}} /\left(R_{\mathrm{t}} f_{\mathrm{t}}+R_{\mathrm{m}}\left(1-f_{\mathrm{t}}\right)\right)$

The mixing curves are shown in Fig. 6. For the model calculation, surface sediments collected from the upper reach of the Pearl River Estuary (with the exclusion of highly polluted station R01) were chosen as the riverine end-member and represented the relatively long term compositional average of the potential riverine input ( $\mathrm{TrOC}$ ) to the ocean, similar to the method described by Prahl et al. (1994). This end-member may provide a better representation of the bulk property of riverine input to the ocean than the universal vascular plant debris end-member, because recent investigations show that terrigenous organic matter is heterogeneous in composition, including at least soils and plant debris sources (Gordon and Goni, 2004, and the references therein). Meanwhile, phytoplankton collected from the northern SCS was chosen as the marine end-member. The $\mathrm{C} / \mathrm{N}$ ratio and $\delta^{13} \mathrm{C}$ of the terrestrial end-member and the marine end-member were $13.3 \pm 1.4$ 


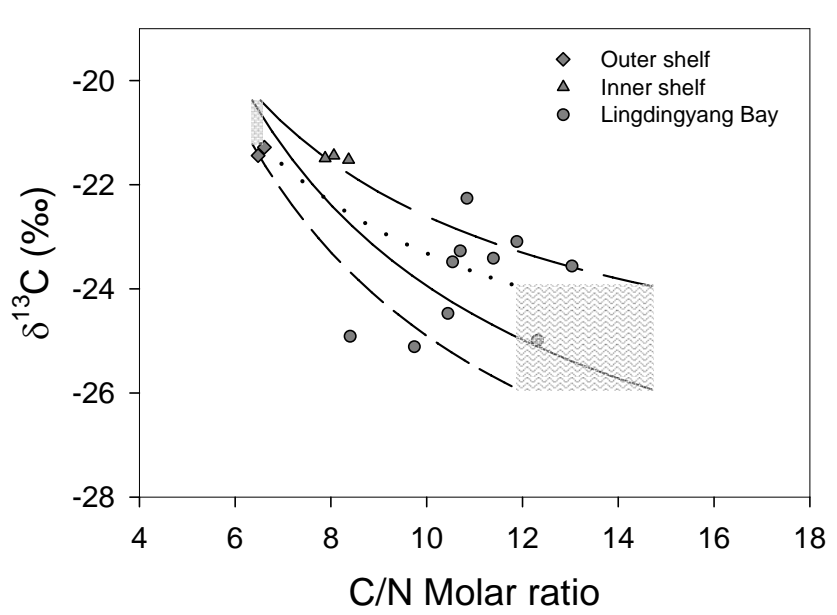

Fig. 6. $\delta^{13} \mathrm{C}$ value of organic carbon versus $\mathrm{C} / \mathrm{N}$ ratio in the Pearl River Estuary and on the shelf of the South China Sea. The curves represent mixing lines between the terrigenous end-member $\left(\delta^{13} \mathrm{C}\right.$ $=-24.9 \pm 1.0 \%, \mathrm{C} / \mathrm{N}=13.3 \pm 1.4$, down-right shadow) and marine end-member $\left(\delta^{13} \mathrm{C}=-20.8 \pm 0.4 \%\right.$ o, $\mathrm{C} / \mathrm{N}=6.46 \pm 0.1$, up-left shadow). Given that both end-members of the terrestrial and marine organic carbon had uncentainties, the mixing curves are also shown with ranges (i.e., different curves). Sediments from the upper reach (excluding R01) of the estuary were served as the terrigenous endmember, while net phytoplankton from the northern South China Sea were served as the marine end-member (see text for details).

and $-24.9 \pm 1.0 \%$, and $6.46 \pm 0.1$ and $-20.8 \pm 0.4 \%$, respectively.

Field observations of carbon isotope composition and $\mathrm{C} / \mathrm{N}$ ratio plot (Fig. 6) showed that the mixing of the riverine endmember with the marine end-member could well explain the carbon isotope composition and $\mathrm{C} / \mathrm{N}$ ratio variations of the sediments along the estuary and continental shelf. The gradual decrease of $\mathrm{C} / \mathrm{N}$ ratios, consistent with progressive enrichment in $\delta^{13} \mathrm{C}$ from the estuary to the inner shelf and then to the outer shelf sediments (Fig. 4), suggested a higher fraction of marine organic matter offshore. Based on the two end-member mixing model, Eqs. (2) and (3), we can estimate the fraction of terrigenous organic nitrogen $\left(f_{\mathrm{t}}\right)$ contributed to the sediments from the Pearl River Estuary and the SCS shelf, as summarized in Table 3. The contribution of terrigenous organic nitrogen to sediment $\mathrm{TN}$ (mostly in the organic form, see discussion above) accounted for, on average, $64 \pm 15 \%$ in Lingdingyang Bay, $20 \pm 3 \%$ on the inner shelf, and $2.8 \pm 0.6 \%$ on the outer shelf. Correspondingly, the contributions of terrigenous organic carbon were, on average, $78 \pm 11 \%$ in Lingdingyang Bay, $34 \pm 4 \%$ on the inner shelf, and $5.5 \pm 1.2 \%$ on the outer shelf. Our data concerning TrOC contribution to the sediment TOC were relatively high but comparable to the results of Zhang et al. (2009), who report that an average of $\sim 55 \%$ bulk TOC in the estuarine sediment is terrestrially sourced. Note that the data reported by Zhang et al. (2009) are based on sediment cores, correspond- ing to an average of $\sim 30-40$ years based on the ${ }^{210} \mathrm{~Pb}$ data. A similar two end-member mixing model based on $\delta^{13} \mathrm{C}$ is used to calculate the contribution of TrOC to sediment TOC by Zhang et al. (2009). The higher contribution of TrOC to surface sediment TOC in our study may thus suggest an increasing input of TrOC from the Pearl River in recent years, which is consistent with the rapid urbanization, industrialization and reclamation in this area.

\subsection{Source characterization of carbohydrates in the Pearl River Estuary and on the SCS shelf}

Carbohydrates are classified as storage and structural polymers. Storage carbohydrates are labile and are rapidly utilized by the in situ heterotrophic organisms. This results in the accumulation of relatively inert structural carbohydrates in marine sediments (Burdige et al., 2000; Hernes et al., 1996; Jensen et al., 2005). The monosaccharide composition of carbohydrates in sediment is a useful tool for identifying the sources of carbohydrates (Campiano and Romano, 1998; Cowie and Hedges, 1984a; Ittekkot et al., 1984; Kerherve et al., 2002; Khodse et al., 2008).

Based on the $\delta^{13} \mathrm{C}$ and $\mathrm{C} / \mathrm{N}$ ratio, we estimated the contribution of terrigenous organic carbon to sediment TOC in the Pearl River Estuary and the adjacent SCS shelf as summarized in Table 3. We categorized sediment samples into two groups, one with high $(\geq 70 \%$, including stations E7A, E8-1, E15 and E30) and one with low ( $\leq 40 \%$, including stations S7-1, S6A and S5) contributions of terrigenous organic carbon. The average neutral sugar compositions of sediment samples rich in TrOC were compared to those poor in TrOC (Fig. 7). Statistical comparisons (t-test) of the means showed that TrOC-rich sediment was enriched in \% ARA $(p<0.1)$ and $\%$ GLU $(\mathrm{p} \leq 0.05)$; but depleted in $\%$ RIB $(p \leq 0.05)$ and $\%$ GAL $(p \leq 0.01)$ relative to TrOC poor sediment. This comparison clearly showed the differences in neutral sugar composition between sediments from different sources (terrestrial versus marine).

GAL was the second most abundant monosaccharide in surface sediments from the estuary and the shelf, and was enriched seawards (Fig. 5). GAL is abundant in terrestrial nonwoody plant tissues (Cowie and Hedges, 1984a), and is one of the major constituents of some phytoplankton cell walls and also bacteria (Cowie and Hedges, 1984a; Hecky et al., 1973). Moreover, the relative abundance of GAL increases during a phytoplankton bloom (Ittekkot et al., 1982). This monosaccharide may have been derived from the mixture of phytoplankton, bacteria and/or terrestrial plant sources, based on the fact that GAL was elevated in the inner shelf (stations S7-1 and S6A-1, Fig. 5), where primary productivity was much higher $\left(3000-4300 \mathrm{mg} \mathrm{C} \mathrm{m}^{-2} \mathrm{~d}^{-1}\right)$ as compared to in the Pearl River Estuary $\left(<100 \mathrm{mg} \mathrm{C} \mathrm{m}^{-2} \mathrm{~d}^{-1}\right)$ (Yin et al., 2004). It is thus suggested that phytoplankton should be the main source of GAL in this area. 


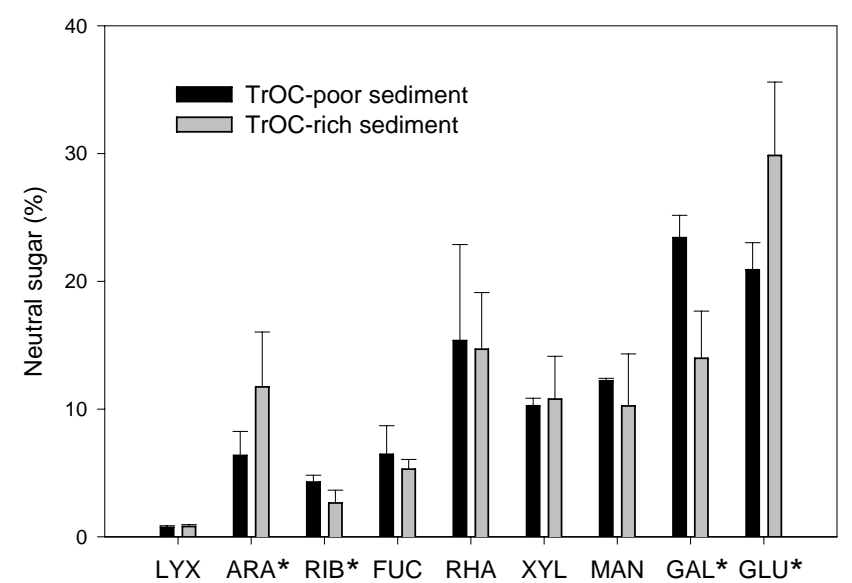

Fig. 7. Average neutral sugar composition (wt \%) of surface sediments showing that sediments from Lingdingyang Bay were enriched in terrestrial organic carbon $(>70 \%)$ and sediments collected from the shelf of the South China Sea had lower terrestrial organic carbon contents $(<40 \%)$. The distinction between TrOC-rich and TrOC-poor is explained in the text. Error bars represent the standard deviation. Sugars marked with "*” signify that statistically significant difference occurred between TrOC-rich and TrOC-poor (see text for details).

ARA accounted for $4.8-17.6 \%$ of the TNS across the studied area. A relatively high \% ARA was observed in the estuarine sediments as compared to the inner shelf and outer shelf sediments (Fig. 5 and Table 4). This relatively high contribution of ARA in the estuarine sediments might be associated with the presence of more structural polysaccharides or arabinogalactans and arabinoxylans in pectin therein (Moers et al., 1989).

XYL accounted for $7.2-15.2 \%$ of the TNS, with almost uniform distribution except at station E8-1. This homogeneity of XYL (9.6-14.6\%) is also observed in surface sediment samples collected from the Mediterranean Sea (Kerherve et al., 2002). The homogeneity of this sugar could have been explained by the balance between various biological sources. $\mathrm{XYL}$ is the second most abundant sugar in terrestrial plants as a constituent of arabinoxylan and arabino-glucuronoxylan (Cowie and Hedges, 1984a; Guggenberger et al., 1994; Ogier et al., 2001). Relatively high XYL (10-23\%) is also observed in the cell lysate organic matter from phytoplanktonic $E$. huxleyi (Biersmith and Benner, 1998). The homogeneity of XYL could also have been due to selective biodegradation of terrestrial XYL during the transfer of organic particles through the estuary. Opsahl and Benner (1999), in a study of carbohydrate composition of different degraded vascular plant tissues, demonstrate that there is a "selective loss" of main GLU and XYL with time. Arnosti (2000), investigating the potential hydrolysis of structurally distinct polysaccharides by extracellular enzymes in bottom water and surface sediment, found that the hydrolysis of xylan is much higher than that of arabinogalactan. That might be the reason why ARA

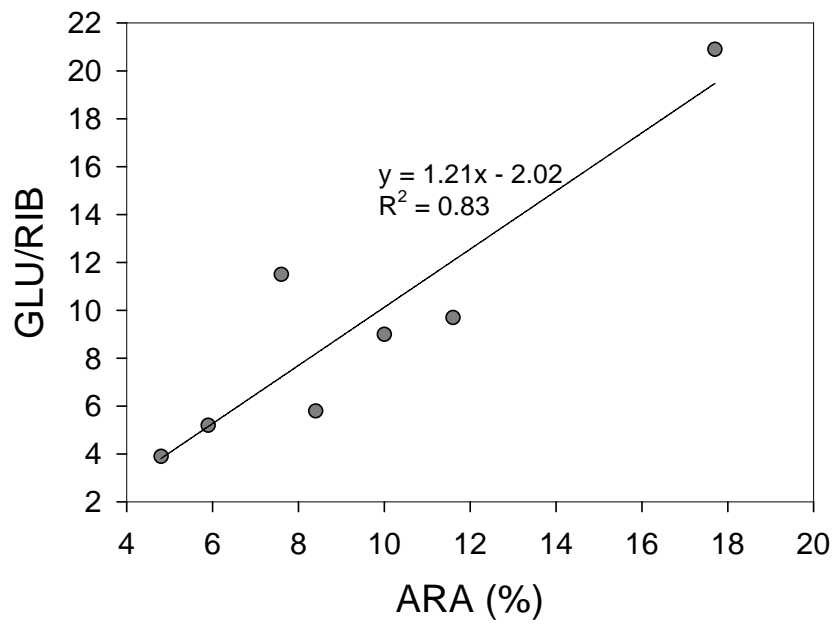

Fig. 8. wt $\%$ arabinose versus glucose/ribose ratio in the surface sediments collected from Lingdingyang Bay and the shelf of the South China Sea.

could be preserved better than XYL in the sediments. Moreover, a positive correlation between the \% ARA and the ratio of GLU/RIB was found in the estuarine and SCS shelf sediments (Fig. 8). Previous studies suggest that terrestrial carbohydrates have a higher GLU/RIB ratio than marine carbohydrates (Cowie and Hedges, 1984a; Degens and Mopper, 1976). A high GLU/RIB ratio coupled with a high \% ARA was observed in Lingdingyang Bay (stations E15, E30 and E8-1), whereas a low GLU/RIB ratio along with a low \% ARA was observed on the SCS shelf (stations S7-1, S6A1 and S5), indicating that terrestrially derived carbohydrate contributed a higher portion to the estuarine sediment and decreased seawards. This notion was further supported by the enrichment of $\delta^{13} \mathrm{C}$ and decrease of the $\mathrm{C} / \mathrm{N}$ ratio offshore.

Relatively high RHA (10.3-24.0\%) was observed in the Pearl River Estuary and SCS shelf sediments as compared to Mandovi Estuary sediments (5.6-11.2\%) and Dabob Bay sediments (9.3-10.3\%) (Cowie and Hedges, 1984a; Khodse et al., 2008). RHA is abundant in bacteria and/or fungi (Cowie and Hedges, 1984a; D'Souza et al., 2005; Hicks et al., 1994), but it is a relatively minor constituent of phytoplanktonic carbohydrate (Biersmith and Benner, 1998; Cowie and Hedges, 1984a). An unusually high value of RHA was found at station E8-1 (20.9\%) and at station S5 $(24.0 \%)$. These high values should not be related to our hydrolysis methods, since these did not show any significant influence on the yields of RHA (Fig. 3). According to Hicks et al. (1994), only bacteria contain such a high proportion of RHA. Alternatively, Biersmith and Benner (1998) found a significant enhancement of RHA in the surface ocean ultrafiltered dissolved organic matter (UDOM) due to diagenetic alteration as compared to the phytoplankton cultured UDOM. We suggest therefore that the relatively high abundance of RHA at stations E8-1 and S5 were associated with a 

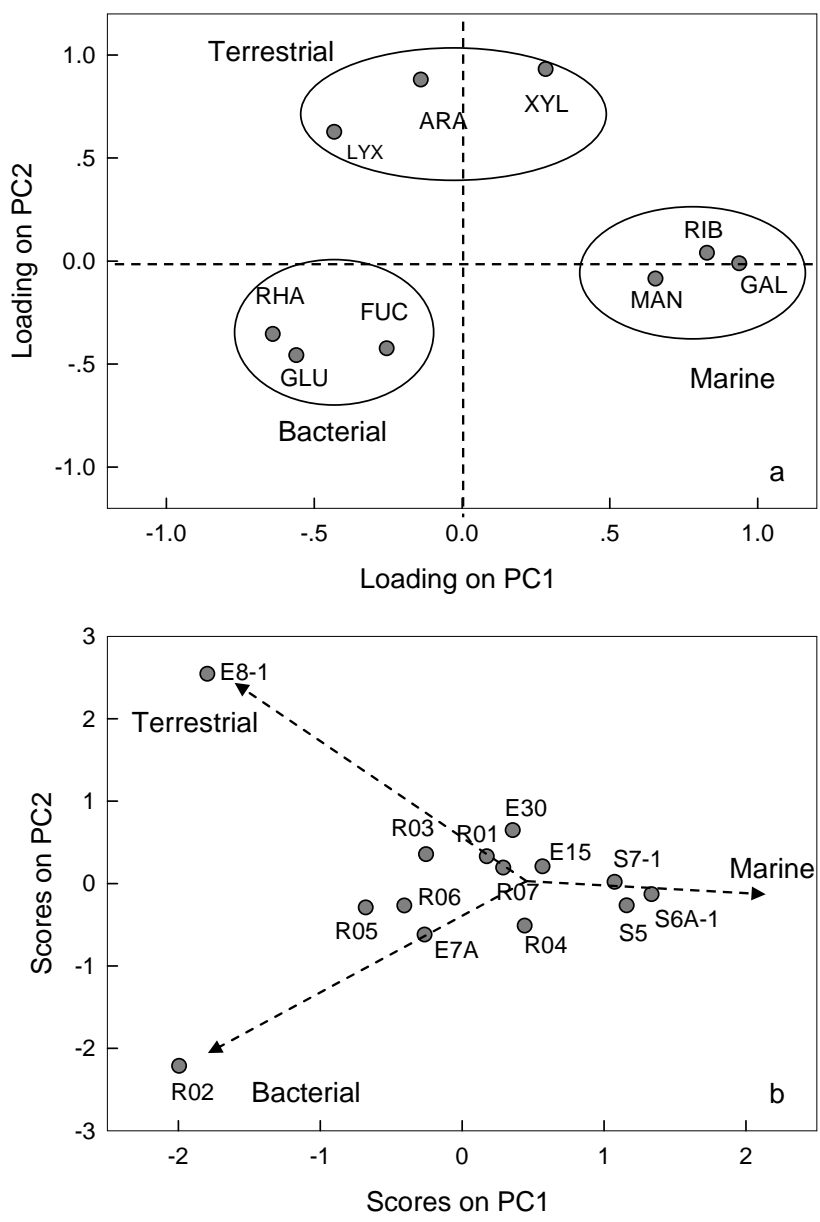

Fig. 9. (a) The loadings on the two principal components for all neutral sugars, and (b) the scores of the two principal components for each sampling site.

bacterial origin and/or bacterial related diagenetic alteration. This notion is also supported by the high percentage of bacterial fatty acids in the sediments of the Pearl River Estuary and SCS shelf (Hu et al., 2006b). According to Hu et al. (2006b), total bacterial fatty acids (the sum of odd carbon-numbered and branched-chain fatty acids) account for $19.8-50.9 \%$ of the total fat acids in the surface sediment in the Pearl River estuary and SCS shelf, and a relatively high percentage of fatty acids are observed in the SCS shelf.

Compared to plant tissues (Cowie and Hedges, 1984a) and phytoplankton (Hernes et al., 1996), the Pearl River Estuary sediments had a significantly higher percentage of FUC. Although FUC is the monomer of a storage polysaccharide in phytoplankton (Cowie and Hedges, 1984a), the association of high FUC with high RHA strongly suggested that bacteria could be the important source of both these deoxyhexoses (Bhosle et al., 1992; Ogier et al., 2001). This high abundance of deoxysugars further confirmed that the organic matter in this area has undergone extensive biodegradation or biotransformation. This sug- gestion was also supported by the relatively high ratios of (FUC+RHA)/(ARA+XYL) (Table 4). Guggenberger et al. (1994) state that (FUC+RHA)/(ARA+XYL) ratios exceeding 0.5 correspond to microbially-altered organic matter.

It is interesting to note that the highest percentage abundance of ARA and XYL along with the lowest percentage of RIB and FUC among the estuarine and shelf sediment samples was found at station E8-1 in Lingdingyang Bay. As shown above, the high ARA abundance was likely to be associated with the dominant contribution of terrestrial carbohydrate. This conclusion was further supported by the highest GLU/RIB and the lowest \% (RIB + FUC) observed at this station. The ratio of GLU/RIB is suggested as an indicator to distinguish the inputs from terrestrial and marine sources, with a high ratio indicating a terrestrial source (Cowie and Hedges, 1984a; Degens and Mopper, 1976). Plant tissues are depleted in \% (RIB+FUC) as compared with plankton and bacteria (Cowie and Hedges, 1984a). The highest GLU/RIB and the lowest \% (RIB + FUC) in this area strongly suggested that carbohydrate was dominantly terrestrially sourced. In addition, this conclusion deduced from carbohydrate composition agreed well with the organic source estimated from the bulk property $\delta^{13} \mathrm{C}$ and $\mathrm{C} / \mathrm{N}$ ratio at this station (Table 3 ). Station E8-1 is located downstream in Lingdingyang Bay near Dayushan Island, and the sediment in this area is characterized as a mixture of sand and clay (Jia and Peng, 2003). This sandy sediment appeared to fail to preserve labile organic matter, resulting in accumulation of degraded refractory TrOC. The low TOC content $(0.67 \%)$ along with the lowest yield of TNS $\left(4.0 \mathrm{mg}(100 \mathrm{mg})^{-1} \mathrm{OC}\right)$ and the lowest percentage of TNS in the TCHO pool (18\%) observed at this station strongly supported such extensive biodegradation. This degradation of TrOC might also have been derived from the soil erosion from Dayushan Island due to the heavy development of this area at the end of the last century, including the construction of Hong Kong International Airport and the Tsing Ma Bridge, as well as Hong Kong Disneyland.

Principal component analysis (PCA) was used to further identify the sources of carbohydrates. Two principal components were identified with eigenvalues $>1$ summing accounting for almost $63 \%$ of the total variance in the sediment monosaccharide composition dataset (Table 5). The first principal component (PC), accounting for $34.1 \%$ of the total variance was positively correlated with GAL, RIB and Man, and negatively correlated with RHA. It is well known that GAL, RIB, and MAN are the dominant components in phytoplankton derived carbohydrates. PC1, therefore, may be categorized as "fresh marine sourced". PC2, accounting for $28.5 \%$ of the total variance was primarily correlated with XYL, ARA, and LYX, which may represent "terrestrial sourced material". The loadings of two principal components (Fig. 9a) showed that nine neutral sugars in the sediments from the Pear River Estuary and SCS shelf had three different sources. GAL, RIB, and MAN had identical sources, likely derived from marine phytoplankton. Similarly, ARA, XYL, 


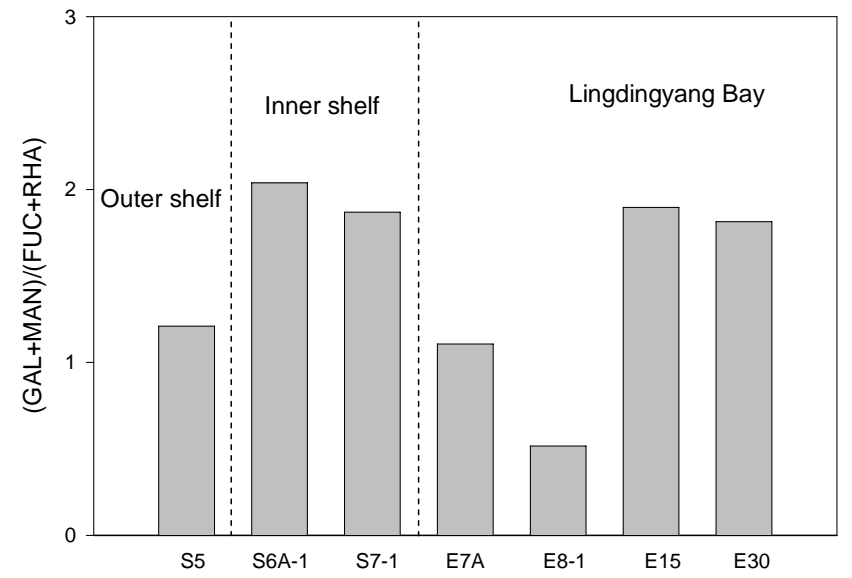

Fig. 10. The ratio of $(\mathrm{GAL}+\mathrm{MAN}) /(\mathrm{FUC}+\mathrm{RHA})$ in the surface sediments collected from Lingdingyang Bay and the SCS shelf.

and LYX may be derived from terrestrial sources, and RHA and FUC may be associated with bacterial sourced material. Note that these PCA results agreed well with what were deduced from the individual neutral sugar analysis (see above discussion). It is interesting to note that GLU had the same source with RHA and FUC. At the same time, GLU is the dominant neutral sugar in storage polysaccharides, like glucan, which appear to be degraded faster than heteropolysaccharides (Hama and Yanagi, 2001). These authors also suggest that GLU may be the dominant neutral sugar in highly degraded and biorefractory DOM (Hama and Yanagi, 2001). The similar origin of GLU and deoxysugars (RHA and FUC) in the Pearl River Estuary might suggest the highly degraded organic carbon therein. The plot of the scores of the two principal components (Fig. 9b) showed a mixture of terrestrial and marine sources of sugars in the Pearl River Estuary and an enhancement of marine sugars along the shelf. The PCA also showed that the carbohydrates in the upper reach of the estuary had been heavily influenced by bacterial reworking processes.

\subsection{Carbohydrate remineralization and diagenesis}

Given their abundance in living organisms, together with their diversity and their biodegradation, carbohydrates have potential as tracers of source and of alteration processes in natural waters. Previous research shows that the distribution and molecular composition of hydrolysable neutral sugars may reflect the preferential utilization of monosaccharides by microorganisms (Biersmith and Benner, 1998; Kerherve et al., 2002; Skoog and Benner, 1997). In addition, neutral sugars are proposed as indicators of the bioactivity and diagenetic status of natural samples (Amon and Benner, 2003; Skoog and Benner, 1997). For example, GLU and GAL are abundant as cellular storage products ( $\beta$-glucan and galactan polymers) in vascular plants and phytoplankton (Kerherve
Table 5. Varimax rotated factor matrix for the whole neutral sugar dataset.

\begin{tabular}{crr}
\hline \multirow{2}{*}{ Variable } & \multicolumn{2}{c}{ Component } \\
& 1 & 2 \\
\hline GAL & $\mathbf{0 . 9 3 7}$ & -0.012 \\
RIB & $\mathbf{0 . 8 2 8}$ & 0.040 \\
MAN & $\mathbf{0 . 6 5 4}$ & -0.085 \\
RHA & $-\mathbf{0 . 6 4 1}$ & -0.355 \\
GLU & -0.561 & -0.457 \\
XYL & 0.283 & $\mathbf{0 . 9 3 2}$ \\
ARA & -0.140 & $\mathbf{0 . 8 8 1}$ \\
LYX & -0.433 & $\mathbf{0 . 6 2 7}$ \\
FUC & -0.255 & -0.423 \\
Explained Variance & $34.10 \%$ & $28.50 \%$ \\
\hline
\end{tabular}

Extraction Method: Principal Component Analysis.

Rotation Method: Varimax with Kaiser Normalization.

Significant factor loadings are bold faced.

et al., 2002, and the references therein), which are easily degraded by heterotrophic organisms (Cowie and Hedges, 1992; Hama and Yanagi, 2001; Hernes et al., 1996). Another hexose, MAN, is rich in the high molecular weight fraction of dissolved organic matter derived from a marine diatom Thalassiosira weissflogii in culture, and is preferentially removed during heterotrophic decomposition (Aluwihare et al., 1997). Therefore, a high abundance of hexoses might suggest more "fresh" organic matter. In contrast, fucoidan is resistant to hydrolysis in bottom water as well as in the surface sediment (Arnosti, 2000), and the deoxysugars FUC and RHA are suggested as good indicators of degraded organic matter (da Cunha et al., 2002; Hedges et al., 1994; Ittekkot and Arain, 1986). Therefore, the ratio of hexoses/deoxysugar may be used as an indicator to discriminate between fresh and refractory organic matter. We excluded the GLU from hexoses by using the (GAL+MAN)/(RHA+FUC) ratio, because the composition of GLU might vary with sources, environmental conditions, diagenetic status, and hydrolysis methods.

The ratios of (GAL+MAN)/(RHA+FUC) in the TrOC rich sediments collected from the northwest of Lingdingyang Bay (stations E30 and E15) were 1.8-1.9, significantly lower than that for terrestrial plant tissues $(>4)$ (Cowie and Hedges, 1984a), indicating that the TrOC transported by the river had undergone extensive biotransformation within the river and/or before entering the river. The lowest value of $(\mathrm{GAL}+\mathrm{MAN}) /(\mathrm{RHA}+\mathrm{FUC})$ was found at station E8-1 (Fig. 10). The lowest level of GAL and MAN at this station (Table 4) might have been associated with the selective degradation of these two monosaccharides. Selective degradation of hexoses was also observed for POM in a Mediterranean river (da Cunha et al., 2002) and for vascular plant tissues (Opsahl and Benner, 1999). It has also been demonstrated that molecular structure can significantly 
affect the degradation rates of carbohydrates (Arnosti, 2000; Arnosti and Repeta, 1994). For example, homopolysaccharide can be degraded much more quickly than heteropolysaccharide in bottom water and surface sediments (Arnosti, 2000). In addition, station E8-1 had the lowest neutral sugar yields $\left(4.0 \mathrm{mg}(100 \mathrm{mg} \mathrm{OC})^{-1}\right)$ and the lowest TNS to TCHO proportion, indicating that carbohydrates in this area had undergone intensive bio-alteration or biodegradation. This decease in TNS and (GAL+MAN)/(RHA+FUC) along the estuary (Table 4, Fig. 10), as well as the significant decrease in the percentage abundance of $\mathrm{TrOC}$ in sediments seawards suggested that TrOC had further biodegraded within the estuary. Downstream of station E8-1, the ratio of $(\mathrm{GAL}+\mathrm{MAN}) /(\mathrm{RHA}+\mathrm{FUC})$ gradually increased to a value of 1.9-2.0 in the inner shelf, which was consistent with the lower limit of the ratio of net marine phytoplankton of 2.0-4.0 in the Pacific Ocean (Hernes et al., 1996), indicating the enhanced contribution of phytoplankton-derived carbohydrate to sediment TOC on the inner shelf. In addition, the simultaneous increase in the yields of TNS suggested that the relatively labile phytoplankton-derived organic matter accumulated on the inner shelf. A relatively low $(\mathrm{GAL}+\mathrm{MAN}) /(\mathrm{RHA}+\mathrm{FUC})$ ratio and TNS yield was found on the outer shelf (station S5), indicating that the higher diagenetic alteration of this organic matter was due to the relatively deep water.

\subsection{Accumulation of terrestrial organic carbon in the Pearl River Estuary and SCS shelf}

Lingdingyang Bay is a large sub-estuary of the Pearl River Estuary. The four outlets are located close together to the north or west of the Bay. Freshwater outflow from the Pearl River sets up a strong density gradient and results in a westward flowing coastal current, usually to the western coast of Lingdingyang Bay. Coarse sediment is deposited in the west part of the Bay due to the relatively strong currents. In contrast, fine silt is deposited in the east part of the Bay (Chen, 1994; Liu et al., 1998). Sedimentation rates based on ${ }^{210} \mathrm{~Pb}$ data differ significantly throughout the estuary: In the west part of the Bay, the sedimentation rates are 1.5$3.8 \mathrm{~cm} \mathrm{yr}^{-1}$ (Lin et al., 1998), while in the east part, the sedimentation rates are $0.4-0.5 \mathrm{~cm} \mathrm{yr}^{-1}$ (Liu et al., 1998; Dai et al., unpublished data). Between the west and east part there is a mid-rate sedimentary area with a sedimentation rate of $1.5-2.5 \mathrm{~cm} \mathrm{yr}^{-1}$ (Chen, 1992). In the north of the Bay the sedimentation rate is $0.9 \mathrm{~cm} \mathrm{yr}^{-1}$ (Dai et al., unpublished data). An extremely high sedimentation rate $\left(9.1 \mathrm{~cm} \mathrm{yr}^{-1}\right)$ was observed in a shallow area near an island, Inner Lingding Island, an area with the highest sedimentation rate (Chen, 1992). The sedimentation rates decrease to $0.3-0.9 \mathrm{~cm} \mathrm{yr}^{-1}$ on the inner shelf (Zhang et al., 2009; Zhang et al., 1998) and to $0.15 \mathrm{~cm} \mathrm{yr}^{-1}$ (Dai et al., unpublished data) on the outer shelf.
An approximation of the sediment deposition flux can be estimated using Eq. (5):

$F_{\mathrm{S}}=R_{\mathrm{S}} \cdot d_{\mathrm{S}}$

The organic carbon accumulation flux can be estimated using Eq. (6):

$F_{\text {org }}=C_{\text {org }} \cdot R_{\mathrm{S}} \cdot d_{\mathrm{S}} / 100$

where $F_{\mathrm{S}}$ and $F_{\text {org }}$ represent the sediment and organic carbon accumulation flux $\left(\mathrm{g} \mathrm{cm}^{-2} \mathrm{yr}^{-1}\right) ; C_{\text {org }}$ is the spatially weighted average organic carbon concentration (wt \%) of the sediments in Lingdingyang Bay; $R_{\mathrm{S}}$ is the spatially weighted average sediment accumulation rate $\left(\mathrm{cm} \mathrm{yr}^{-1}\right)$ in the Bay; and $d_{\mathrm{S}}$ is the arithmetic average "dry bulk density" $\left(\mathrm{g} \mathrm{cm}^{-3}\right)$ of the sediment. The "dry bulk density" of the sediment is equivalent to dry sediment density $\times(1-$ porosity $)$, and calculated from the dry weight and the initial volume of the sediment samples (Lin et al., 1998; Haas et al., 1997). The deviation of $F_{\text {org }}$ was calculated using an error propagation formula. We used the arithmetic average sediment dry density to estimate the organic carbon accumulation, because the spatial variation of the sediment density was not significant, and the coefficient of the variation was no more than $16 \%$.

Based on the sedimentation rates summarized above, a spatially weighted average sedimentation rate was calculated as $1.9 \pm 1.2 \mathrm{~cm} \mathrm{yr}^{-1}$ for Lingdingyang Bay. The average dry bulk density of the sediment is $0.79 \pm 0.13 \mathrm{~g} \mathrm{~cm}^{-3}$ for the Bay (Lin et al., 1998). As a first order estimation the sediment deposition flux could be $1.5 \pm 0.9 \mathrm{~g} \mathrm{~cm}^{-2} \mathrm{yr}^{-1}$. The spatially weighted average organic concentration of the Lindingyang Bay was $0.98 \pm 0.12 \%$. The organic matter sedimentary flux in the Bay was then calculated as $15 \pm 9 \mathrm{mg}$ $\mathrm{C} \mathrm{cm}-2 \mathrm{yr}^{-1}$. The surface area of Lingdingyang Bay is $\sim 1600 \mathrm{~km}^{2}$ (digitization from the navigation map, 2005 version), and thus the sediment accumulation in this area was estimated as $2.4 \pm 1.5 \times 10^{13} \mathrm{~g} \mathrm{yr}^{-1}$, while the organic matter accumulation was estimated as $2.4 \pm 1.5 \times 10^{11} \mathrm{~g} \mathrm{C} \mathrm{yr}^{-1}$. Given that TrOC accounted for $78 \pm 11 \%$ of the TOC in this area, the TrOC accumulation in Lingdingyang Bay would have been $1.8 \pm 1.1 \times 10^{11} \mathrm{~g} \mathrm{C} \mathrm{yr}^{-1}$.

Long term (1993-2002) average river transport of suspended substances to Lingdingyang Bay is estimated as $3.3 \times 10^{13} \mathrm{~g} \mathrm{yr}^{-1}$ (Dai et al., 2007), most (92-96\%) of which occurs during the wet season (April to September) (Wai et al., 2004, and the reference therein). The particulate organic content (\%POC) of the lower Pearl River is $1.09 \pm 0.29 \%$ in summer, $2.19 \pm 0.12 \%$ in spring, $2.00 \pm 0.46 \%$ in autumn, and $4.69 \pm 1.51 \%$ in winter (Dai et al., unpublished data). Here we adopted a \%POC of $1.09 \pm 0.29 \%$ as a lower limit to estimate TrOC input to Lingdingyang Bay, which was at

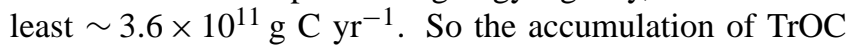
in the Bay accounted for $\sim 50 \%$ of the total POC loads at most, whereas sediment deposition accounted for $\sim 73 \%$ of the suspended substances transported to the Bay. The accumulation efficiency of TrOC was significantly lower than the 
sediment burial efficiency in the Bay. A low accumulation efficiency of riverine POC is also found in the Amazon Delta $(\sim 25 \%)$, Columbia and Fly $(<50 \%)$ deltaic systems (Keil et al., 1997). Moreover, Keil et al. (1997) find that the loss of TrOC occurs in all size fractions, indicating that physical sorting of organic-rich fine particles to distal sites would not be a reasonable explanation for the carbon deficit. In our study, this low accumulation efficiency of TrOC along with the absolute TOC content of sediment declined seawards and the portion of TrOC decreased offshore indicating that riverine POC was likely to have undergone a significant degradation and transformation during transportation throughout the Pearl River Estuary. This high degradation of TrOC was also reflected in the molecular-level identification of the carbohydrate composition of the same sediments, such as the TNS yields and (GAL+MAN)/(FUC+RHA) ratios that were found to decrease along the Pearl River Estuary.

\section{Concluding remarks}

Monosaccharide compositions and their ratios indicated that the organic matter in the sediments from the Pearl River Estuary and SCS shelf was mainly derived from terrestrial and phytoplankton originating materials, with a significantly higher contribution of terrestrial material to the estuarine sediments as compared to the shelf sediments. The TNS yields and $(\mathrm{GAL}+\mathrm{MAN}) /(\mathrm{RHA}+\mathrm{FUC})$ decreased along the estuary to their lowest values in the downstream Lingdingyang Bay, and then increased to relatively higher values on the inner shelf where primary productivity was enhanced. These contrasting distribution patterns indicated that the biodegradation of $\mathrm{TrOC}$ is the main process controlling the distribution of carbohydrate in the estuary, whereas phytoplankton production is the main process controlling the distribution of carbohydrate on the shelf. Our two end-member model based on the $\mathrm{C} / \mathrm{N}$ ratio and $\delta^{13} \mathrm{C}$ supported the view that TrOC was deposited primarily in the estuary and inner continental shelf and that little was exported to the outer shelf. At the same time, the relative abundance of neutral monosaccharides combined with the $\mathrm{C} / \mathrm{N}$ ratio and $\delta^{13} \mathrm{C}$ strongly suggested that TrOC had undergone further intensive degradation through the water column and in the surface sediments in the estuary.

A preliminary sediment budget based on calculated regional accumulation rates showed that only $\sim 50 \%$ of terrestrial POC was accumulated in Lingdingyang Bay. In contrast to the $\sim 73 \%$ bulk sediment burial efficiency, this markedly lower accumulation efficiency of terrestrial organic matter suggested again that the terrestrial POC had undergone significant degradation and transformation during transportation throughout the Pearl River Estuary.

The combination of bulk organic geochemical parameters with molecular biomarkers, which this study adopted, has been demonstrated to be a useful tool for better defining both qualitatively and quantitatively the sources of organic matter within the Pearl River Estuary and the adjacent SCS shelf.

Acknowledgements. This research was supported by the Natural Science Foundation of China through grants \#49825111, \#40176025 and \#90211020. We thank Fan Zhang, Wuqi Ruan and Wei Junfeng along with the crew of Yanping II for their assistance during the sampling cruises. We thank the Guiyang Institute of Geochemistry for providing the mass spectrometer for carbon isotope analysis. We also thank John Hodgkiss for his assistance with English. Reviews and/or comments from three anonymous referees greatly improved the quality of the paper.

Edited by: J. Middelburg

\section{References}

Aller, R. C., Blair, N. E., Zia, Q., and Rude, P. D.: Remineralization rates, recycling and storage of carbon in Amazon shelf sediments, Cont. Shelf Res., 17, 753-786, 1996.

Aluwihare, L. I., Repeta, D. J., and Chen, R. F.: A major biopolymeric component to dissolved organic carbon in surface sea water, Nature, 387, 166-169, 1997.

Amelung, W., Cheshire, M. V., and Guggenberger, G.: Determination of neutral and acidic sugars in soil by capillary gas-liquid chromatography after trifluoroacetic acid hydrolysis, Soil Biol. Biochem., 28, 1631-1639, 1996.

Amon, R. M. W. and Benner, R.: Combined neutral sugars as indicators of the diagenetic state of dissolved organic matter in the Arctic Ocean, Deep-Sea Res. Part I-Oceanographic Research Papers, 50, 151-169, 2003.

Arnosti, C.: Substrate specificity in polysaccharide hydrolysis: Contrasts between bottom water and sediments, Limnol. Oceanogr., 45, 1112-1119, 2000.

Arnosti, C. and Repeta, D. J.: Oligosaccharide degradation by anaerobic marine bacteria: characterization of an experimental system to study polymer degradation in sediments, Limnol. Oceanogr., 39, 1865-1877, 1994.

Benner, R. and Opsahl, S.: Molecular indicators of the sources and transformations of dissolved organic matter in the Mississippi river plume, Org. Geochem., 32, 597-611, 2001.

Bergamaschi, B. A., Tsamakis, E., and Keil, R. G.: The effect of grain size and surface area on organic matter, lignin and carbohydrate concentration, and molecular compositions in Peru Margin sediments, Geochim. Cosmoch. Acta, 61, 1247-1260, 1997.

Bergamaschi, B. A., Walters, J. S., and Hedges, J.I.: Distributions of uronic acids and O-methyl sugars in sinking and sedimentary particles in two coastal marine environments, Geochim. Cosmochim. Acta, 63, 413-425, 1999.

Bernardes, M. C., Martinelli, L. A., Krusche, A. V., Gudeman, J., Moreira, M., Victoria, R. L., Ometto, J., Ballester, M. V. R., Aufdenkampe, A. K., Richey, J. E., and Hedges, J. I.: Riverine organic matter composition as a function of land use changes, Southwest Amazon, Ecological Applications, Supplement, 14, S263-S279, 2004.

Berner, R. A.: Burial of organic carbon and pyrite sulfur in the modern ocean: its geochemical and environmental significance, Am. J. Sci., 282, 451-473, 1982. 
Bhosle, N. B., Sankaran, P. D., and Wagh, A. B.: Monosaccharide composition of suspended particles from the Bay of Bengal, Oceanologica Acta, 15, 279-286, 1992.

Biersmith, A. and Benner, R.: Carbohydrates in phytoplankton and freshly produced dissolved organic matter, Mar. Chem., 63, 131144, 1998.

Boschker, H. T. S., Dekkers, R. P., and Cappenberg, T. E.: Sources of organic carbon in the littoral of Lake Gooimeer as indicated by stable carbon isotope and carbohydrate composition, Biogeochem., 29, 89-105, 1995.

Burdige, D. J., Skoog, A., and Gardner, K.: Dissolved and particulate carbohydrates in contrasting marine sediments, Geochim. Cosmochim. Acta, 64, 1029-1041, 2000.

Buhamra, S. S., Bouhamra, W. S., and Elkilani, A. S.: Assessment of air quality in ninety-nine residences of Kuwait, Environ. Technol., 19, 357-368, 1998.

Cai, D. L., Tan, F. C., and Edmond, J. M.: Sources and transport of particulate organic carbon in the Amazon River and estuary, Estuar. Coast. Shelf Sci., 26, 1-14, 1988.

Campiano, A. M. and Romano, J. C.: Amino Acids and Monosaccharides in sediments in the vicinity of an urban sewer, Marine Environ. Res., 25, 291-313, 1998.

Chen, Y.: Modern sedimentary velocity and sedimentary environment in the Pearl River mouth, Acta Scientiarum Naturalium University Sunyatseni, 31, 100-107, 1992 (in Chinese).

Chen, Y.: Character of heavy mineral in the surface sediments of Lingding Yang in the Pearl River mouth and their reflection to the invasion of shelf's water, Acta Scientiarum Naturalium University Sunyatseni, 33, 103-110, 1994 (in Chinese).

Cowie, G. L. and Hedges, J. I.: Carbohydrate sources in a coastal marine environment, Geochim. Cosmochim. Acta, 48, 20752087, 1984a.

Cowie, G. L. and Hedges, J. I.: Determination of neutral sugars in plankton, sediments, and wood by capillary gas chromatography of equilibrated isomeric mixtures, Anal. Chem., 56, 497-504, $1984 b$

Cowie, G. L. and Hedges, J. I.: Role of anoxia in organic matter preservation in coastal sediments: Relative stabilities of the major biochemicals under oxic and anoxic depositional conditions, Org. Geochem., 19, 229-234, 1992.

D’Souza, F., Garg, A., and Bhosle, N. B.: Seasonal variation in the chemical composition and carbohydrate signature compounds of biofilm, Aquat. Microb. Ecol., 41, 199-207, 2005.

da Cunha, L. C., Serve, L., and Blazi, J.-L.: Neutral sugars as biomarkers in the particulate organic matter of a French Mediterranean river, Org. Geochem., 33, 953-964, 2002.

Dai, S., Yang, S., and Cai, A.: Variation of sediment discharge of the Pearl River Basin from 1955 to 2005, Acta Geographica Sinica, 62, 545-554, 2007 (in Chinese).

Dai, M., Guo, X., Zhai, W., Yuan, L., Wang, B., Wang, L., Cai, P., Tang, T., and Cai, W.-J.: Oxygen depletion in the upper reach of the Pearl River Estuary during a winter drought, Mar. Chem., 102, 159-169, 2006.

de Haas, H., van Weering, T. C. E., and de Stigter, H.: Organic carbon in shelf seas: sinks or sources, processes, and products, Cont. Shelf Res., 22, 691-717, 2002.

de Haas, H., Boer, W., and van Weering, T. C. E.: Recent sedimentation and organic carbon burial in a shelf sea: the North Sea, Mar. Geol., 144, 131-146, 1997.
Decho, A. W.: Microbial exopolymer secretions in ocean environments, their roles in food webs and marine processes, Oceanogr. Mar. Biol. Annual Review, 28, 73-153, 1990.

Degens, E. R. and Mopper, K.: Factors controlling the distribution and early diagenesis of organic material in marine sediments, in: Chemical Oceanography, edited by: Riley, J. P. and Chester, R., Academic Press, London, p. 59-113, 1976.

Fengel, D. and Wegener, G.: Hydrolysis of polysaccharides with trifluoroacetic acid and its application to rapid wood and pulp analysis, in: Hydrolysis of Cellulose: Mechanisms of Enzymatic and Acid Catalysis, edited by: Brown, R. D. and Jurasek, L., Advances in Chemistry Series 181, American Chemical Society, Washington, p. 146-158, 1979.

Goering, J., Alexander, V., and Haubenstock, N.: Seasonal variability of stable carbon and nitrogen isotope ratios of organisms in a North Pacific bay, Estuar. Coast. Shelf Sci., 30, 239-260, 1990.

Goni, M. A., Ruttenberg, K. C., and Eglinton, T. I.: Sources and contribution of terrigenous organic carbon to surface sediments in the Gulf of Mexico, Nature, 389, 275-278, 1997.

Goni, M. A., Ruttenberg, K. C., and Eglinton, T. I.: A reassessment of the sources and importance of land-derived organic matter in surface sediments from the Gulf of Mexico, Geochim. Cosmochim. Acta, 62, 3055-3075, 1998.

Gordon, E. S. and Goni, M. A.: Sources and distribution of terrigenous organic matter delivered by the Atchafalaya River to sediments in the northern Gulf of Mexico, Geochim. Cosmochim. Acta, 67, 2359-2375, 2003.

Gordon, E. S. and Goni, M. A.: Controls on the distribution and accumulation of terrigenous organic matter in sediments from the Mississippi and Atchafalaya river margin, Mar. Chem., 92, 331-352, 2004.

Guggenberger, G., Christensen, B. T., and Zech, W.: Land-use effects on the composition of organic matter in particle-size separates of soil: I. Lignin and carbohydrate signature, Eur. J. Soil Sci., 45, 449-458, 1994.

Guo, X., Dai, M., Zhai, W., Cai, W.-J., and Chen, B.: $\mathrm{CO}_{2}$ flux and seasonal variability in a large subtropical estuarine system, the Pearl River Estuary, China, J. Geophys. Res.-Biogeoscience, 114, G03013, doi:10.1029/2008JG000905, 2009.

Hama, T. and Yanagi, K.: Production and neutral aldose composition of dissolved carbohydrates excreted by natural marine phytoplankton populations, Limnol. Oceanogr., 46, 1945-1955, 2001.

Harrison, R. M., Smith, D. J. T., and Luhana, L.: Source apportionment of atmospheric polycyclic aromatic hydrocarbons collected from an urban location in Birmingham, UK Environmental Science and Technology, 30, 825-832, 1996.

Hayes, J. M.: Factors controlling $\delta^{13} \mathrm{C}$ contents of sedimentary organic compounds: Principles and evidence, Mar. Geol., 113, 111-125, 1993.

He, B., Dai, M., Cao, L., Xu, L., Huang, W., and Wang, X.: Application of capillary gas chromatography to the determination of the composition of polysaccharides in marine sediments, Oceanologia et Limnologia Sinica, 34, 233-240, 2003 (in Chinese).

He, B., Dai, M., Zhai, W., Wang, L., Wang, K., Chen, j., Lin, J., Han, A., and Xu, Y.: Distribution, degradation and dynamics of dissolved organic carbon and its major compound classes in the Pearl River estuary, China, Mar. Chem., 119, 52-64, 2010. 
Hecky, R. E., Mopper, K., Kilham, P., and Degens, E. T.: The amino acid and sugar composition of diatom cell walls, Mar. Biol., 19, 323-331, 1973.

Hedges, J. I., Clark, W. A., Quay, P. D., Richey, J. E., Devol, A. H., and Santos, U. d. M.: Compositions and fluxes of particulate organic material in the Amazon River, Limnol. Oceanogr., 31, 717-738, 1986.

Hedges, J. I., Cowie, G. L., Richey, J. E., Quay, P. D., Benner, R., Strom, M., and Forsberg, B. R.: Origins and processing of organic matter in the Amazon River as Indicated by carbohydrates and amino acids, Limnol. Oceanogr., 39, 743-761, 1994.

Hedges, J. I. and Keil, R. G.: Sedimentary organic matter preservation: an assessment and speculative synthesis, Mar. Chem., 49, 81-115, 1995.

Hedges, J. I., Keil, R. G., and Benner, R.: What happens to terrestrial organic matter in the ocean?, Org. Geochem., 27, 195-212, 1997.

Hedges, J. I. and Oades, J. M.: Comparative organic geochemistries of soils and marine sediments, Org. Geochem., 27, 319-361, 1997.

Hedges, J. I. and Parker, P. L.: Land-derived organic matter in surface sediments from the Gulf of Mexico, Geochim. Cosmochim. Acta, 40, 1019-1029, 1976.

Hernes, P. J., Hedges, J. I., Peterson, M. L., Wakeham, S. G., and Lee, C.: Neutral carbohydrate geochemistry of particulate material in the central equatorial Pacific, Deep Sea Res. Part II: Topical Studies in Oceanography, 43, 1181-1204, 1996.

Hicks, R. E., Owen, C. J., and Aas, P.: Deposition, resuspension, and decomposition of particulate organic matter in the sediments of Lake Itasca, Minnesota, USA, Hydrobiologia, 284, 79-91, 1994.

Hu, J., Peng, P., and Chivas, A. R.: Molecular biomarker evidence of origins and transport of organic matter in sediments of the Pearl River estuary and adjacent South China Sea, Appl. Geochem., 24, 1666-1676, 2009.

Hu, J., Peng, P., Jia, G., Mai, B., and Zhang, G.: Distribution and sources of organic carbon, nitrogen and their isotopes in sediments of the subtropical Pearl River estuary and adjacent shelf, Southern China, Mar. Chem., 98, 274-285, 2006a.

$\mathrm{Hu}$, J., Zhang, H., and Peng, P.: Fatty acid composition of surface sediments in the subtropical Pearl River estuary and adjacent shelf, Southern China, Estuar. Coast. Shelf Sci., 66, 346-356, $2006 \mathrm{~b}$.

Ittekkot, V. and Arain, R.: Nature of particulate organic matter in the river Indus, Pakistan, Geochim. Cosmochim. Acta, 50, 16431653, 1986.

Ittekkot, V., Deuser, W. G., and Degens, E. T.: Seasonality in the fluxes of sugars amino acids and amino sugars to the deep ocean: Sargasso Sea, Deep-Sea Res. A-Oceanographic Research Papers, 31, 1057-1069, 1984.

Ittekkot, V., Egon, T. D., and Brockmann, U.: Monosaccharide composition of acid-hydrolyzable carbohydrates in particulate matter during a plankton bloom, Limnol. Oceanogr., 27, 770$776,1982$.

Jennerjahn, T. C. and Ittekkot, V.: Changes in organic matter from surface waters to continental slope sediments off the Sao Francisco River, eastern Brazil, Mar. Geol., 161, 129-140, 1999.

Jensen, M. M., Holmer, M., and Thamdrup, B.: Composition and diagenesis of neutral carbohydrates in sediments of the Baltic-
North Sea transition, Geochim. Cosmochim. Acta, 69, 40854099, 2005.

Jia, G.-D. and Peng, P.-A.: Temporal and spatial variations in signatures of sedimented organic matter in Lingding Bay (Pearl estuary), southern China, Mar. Chem., 82, 47-54, 2003.

Keil, R. G., Mayer, L. M., Quay, P. D., Richey, J. E., and Hedges, J. I.: Loss of organic matter from riverine particles in deltas, Geochim. Cosmochim. Acta, 61, 1507-1511, 1997.

Keil, R. G., Tsamakis, E., Giddings, J. C., and Hedges, J. I.: Biochemical distributions (amino acids, neutral sugars, and lignin phenols) among size-classes of modern marine sediments from the Washington coast, Geochim. Cosmochim. Acta, 62, 13471364, 1998.

Kerherve, P., Buscail, R., Gadel, F., and Serve, L.: Neutral monosaccharides in surface sediments of the northwestern Mediterranean Sea, Org. Geochem., 33, 421-435, 2002.

Khodse, V. B., Fernandes, L., Bhosle, N. B., and Sardessai, S.: Carbohydrates, uronic acids and alkali extractable carbohydrates in contrasting marine and estuarine sediments: Distribution, size fractionation and partial chemical characterization, Org. Geochem., 39, 265-283, 2008.

Kuwae, M., Yamaguchi, H., Tsugeki, N. K., Miyasaka, H., Fukumori, K., Ikehara, M., Genkai-Kato, M., Omori, K., Sugimoto, T., Ishida, S., and Takeoka, H.: Spatial distribution of organic and sulfur geochemical parameters of oxic to anoxic surface sediments in Beppu Bay in southwest Japan, Estuar. Coast. Shelf Sci., 72, 348-358, 2007.

Lin, R., Min, Y., Wei Keqin., Zhang, G., Yu, F., and Yu, Y.: ${ }^{210} \mathrm{~Pb}-$ Data of sediment cores from the Pearl River mouth and its environmental Geochemistry implication, Geochimica, 27, 401-411, 1998 (in Chinese).

Liu, K.-K., Kao, S.-J., Hu, H.-C., Chou, W.-C., Huang, G.-W., and Tseng, C.-M.: Carbon isotopic composition of suspended and sinking particulate organic matter in the northern South China Sea - From production to deposition, Deep-Sea Res. II, 54, 1504-1527, 2007

Liu, Y., Han, M., Wu, L., and Nobuo, M.: Recent evolution of outlets in Zhujiang River delta and the prospect for land reclamation, Acta Geographica Sinica, 53, 492-500, 1998 (in Chinese).

Marchand, C., Disnar, J. R., Lallier-Verges, E., and Lottier, N.: Early diagenesis of carbohydrates and lignin in mangrove sediments subject to variable redox conditions (French Guiana), Geochim. Cosmochim. Acta, 69, 131-142, 2005.

Meybeck, M.: Carbon, nitrogen, and phosphorus transport by world rivers, Am. J. Sci., 282, 401-450, 1982.

Meyers, P. A.: Preservation of elemental and isotopic source identification of sedimentary organic matter, Chem. Geol., 114, 289302, 1994.

Middelburg, J. J. and Nieuwenhuize, J.: Carbon and nitrogen stable isotopes in suspended matter and sediments from the Schelde Estuary, Mar. Chem., 60, 217-225, 1998.

Miyajima, T., Ogawa, H., and Koike, I.: Alkali-extractable polysaccharides in marine sediments: Abundance, molecular size distribution, and monosaccharide composition, Geochim. Cosmochim. Acta, 65, 1455-1466, 2001.

Moers, M. E. C., Boon, J. J., De Leeuw, J. W., Baas, M., and Schenck, P. A.: Carbohydrate speciation and Py-MS mapping of peat samples from a subtropical open marsh environment, Geochim. Cosmochim. Acta, 53, 2011-2021, 1989. 
Mopper, K.: Sugars and uronic acids in sediment and water from the Black Sea and North Sea with emphasis on analytical techniques, Mar. Chem., 5, 585-603, 1977.

Ogier, S., Disnar, J.-R., Alberic, P., and Bourdier, G.: Neutral carbohydrate geochemistry of particulate material (trap and core sediments) in an eutrophic lake (Aydat, France), Org. Geochem., 32, 151-162, 2001.

Opsahl, S. and Benner, R.: Characterisation of carbohydrates during early diagenesis of five vascular plant tissues, Org. Geochem., 30, 83-94, 1999.

Pakulski, J. D. and Benner, R.: An improved method for the hydrolysis and MBTH analysis of dissolved and particulate carbohydrates in seawater, Mar. Chem., 40, 143-160, 1992.

Panagiotopoulos, C. and Sempéré, R.: Analytical methods for the determination of sugars in marine samples: A historical perspective and future directions, Limnol. Oceanogr., Methods, 3, 419453, 2005.

Prahl, F. G., Ertel, J. R., Goni, M. A., Sparrow, M. A., and Eversmeyer, B.: Terrestrial organic carbon contributions to sediments on the Washington margin, Geochim. Cosmochim. Acta, 58, 3035-3035, 1994.

Ramaswamy, V., Gaye, B., Shirodkar, P. V., Chivas, A. R., Wheeler, D., and Thwin, S.: Distribution and sources of organic carbon, nitrogen and their isotopic signatures in sediments from the Ayeyarwady (Irrawaddy) continental shelf, northern Andaman Sea, Mar. Chem., 111, 137-150, 2008.
Skoog, A. and Benner, R.: Aldoses in various size fractions of marine organic matter: Implications for carbon cycling, Limnol. Oceanogr., 42, 1803-1813, 1997.

Tibbles, B. J., Lucas, M. I., Coyne, V. E., and Newton, S. T.: Nitrogenase activity in marine sediments from a temperate saltmarsh lagoon: modulation by complex polysaccharides, ammonium and oxygen, J. Exp. Mar. Biol. Ecol., 184, 1-20, 1994.

Wai, O. W. H., Wang, C. H., Li, Y. S., and Li, X. D.: The formation mechanisms of turbidity maximum in the Pearl River estuary, China, Mar. Pollut. Bull., 48, 441-448, 2004.

Yin, K., Zhang, J., Qian, P.-Y., Jian, W., Huang, L., Chen, J., and $\mathrm{Wu}, \mathrm{M}$. C. S.: Effect of wind events on phytoplankton blooms in the Pearl River estuary during summer, Cont. Shelf Res., 24, 1909-1923, 2004.

Yu, F., Zong, Y., Lloyd, J. M., Huang, G., Leng, M. J., Kendrick, C., Lamb, A. L., and Yim, W. W.-S.: Bulk organic $\delta^{13} \mathrm{C}$ and C/N as indicators for sediment sources in the Pearl River delta and estuary, southern China, Estuar. Coast. Shelf Sci., 87, 618-630, 2010.

Zhang, L., Yin, K., Wang, L., Chen, F., Zhang, D., and Yang, Y.: The sources and accumulation rate of sedimentary organic matter in the Pearl River Estuary and adjacent coastal area, Southern China, Estuar. Coast. Shelf Sci., 85, 190-196, 2009.

Zhang, Z., Chen, Z., Xu, L., and Hong, H.: Modern sedimentary rate and heavy metal pollution in the Pearl River Estuary, Marine Science Bulletin, 17, 53-57, 1998 (in Chinese). 